\title{
TBDY 2018'e Göre Geoteknik Tasarım: Sıvılaşma ve Yapı-Kazık-Zemin Etkileşimi Analizleri
}

\author{
Ozan ALVER ${ }^{1}$ \\ Atila SEZEN ${ }^{2}$ \\ E. Ece ESELLER-BAYAT ${ }^{3}$
}

ÖZ

Bu çalışma Türkiye Bina Deprem Yönetmeliği (TBDY) 2018'e göre sıvılaşma potansiyeli olan zeminlerde derin temel tasarım adımlarını irdelemektedir. Bu amaçla, 1 Ocak 2019'dan itibaren yürürlükte olan yeni TBDY'e göre Mudanya'da inşa edilmesi planlanan bir apartman yapısının sıvılaşma ve zemin-kazık-yapı etkileşim analizleri de dahil olmak üzere geoteknik mühendislik tasarım aşamaları gerçekleştirilmiş ve sunulmuştur. Sıvılaşma analizlerindeki belirsizlikler, deprem kayıtlarının elde edilmesindeki ve ölçeklenmesindeki zorluklar, oturma sınır değerlerinin yönetmelikte belirtilmemesi ve Yöntem III'teki kinematik ve eylemsizlik etkileşimi analizi yaklaşımlarındaki farklı davranış kabullerine bu çalışmada dikkat çekilmiş ve tartışılmıştır.

Anahtar Kelimeler: TBDY, arazi zemin modeli, derin temel sistemi tasarımı, sıvılaşma, yapı- kazık-zemin etkileşimi.

\section{ABSTRACT \\ Geotechnical Design with Respect to TBDY-2018: Liquefaction and Soil-Pile-Structure Interaction Analyses}

This study explores the design steps of a building foundation in liquefiable soils according to TBDY 2018. For this purpose, geotechnical engineering design was performed in stages including the liquefaction and soil-pile-structure interaction analyses. The problematic issues such as the determination of $\mathrm{M}_{\mathrm{w}}$ values that were used during liquefaction analyses, the search for time histories records to be scaled, the absence of recommended tolerable limits

\footnotetext{
Not: Bu yazı

- Yayın Kurulu’na 29 Mayıs 2020 günü ulaşmıștır. 9 Kasım 2020 günü yayımlanmak üzere kabul edilmiştir.

- 30 Kasım 2021 gününe kadar tartışmaya açıktır.

- https://doi.org/10.18400/tekderg.744891
}

1 İstanbul Teknik Üniversitesi, İnşaat Mühendisliği Bölümü, İstanbul - alver16@itu.edu.tr https://orcid.org/0000-0002-5510-7169

2 İstanbul Teknik Üniversitesi, İnşaat Mühendisliği Bölümü, İstanbul - sezenati@itu.edu.tr https://orcid.org/0000-0001-9860-5486

3 İstanbul Teknik Üniversitesi, İnşaat Mühendisliği Bölümü, İstanbul - ebayat@itu.edu.tr https://orcid.org/0000-0002-5774-4911 
for the foundation soil settlements and different assumptions underlying the kinematic and inertial interaction approaches for Method III were addressed.

Keywords: TBDY (Turkish Earthquake Resistant Building Design Regulations), site soil model, pile foundation design, liquefaction, soil-pile-structure interaction.

\section{GİRIŞ}

1 Ocak 2019 tarihi itibariyle yürürlüğe giren Türkiye Bina Deprem Yönetmeliği, TBDY2018 [1], kendisinden önceki Deprem Bölgelerinde Yapılacak Binalar Hakkında Yönetmelik (DBYBHY-2007) ile kıyaslandığında yaklaşım, hesap yöntemleri ve bunların uygulanma kriter ve kapsamları açısından önemli farklılıklar göstermektedir. Bu sebeple TMMOBİnşaat Mühendisleri Odasının (İMO) desteği ve yürütücülüğü ile yönetmeliğin hazırlanmasında aktif olarak yer alan bilim insanları da dahil olmak üzere ilgili bilim insanı ve inşaat mühendislerinin katılımıyla Türkiye'nin farklı illerinde çok sayıda tanıtım ve bilgilendirme toplantısı düzenlenmiştir. Bu çalışmada da benzer bir amaçla yeni yönetmeliğe dayalı olarak yürütülmesi gereken geoteknik tasarım ve bu bağlamdaki sıvılaşma analizi ve temel sistemi tasarımı aşamaları bir vaka çalışması vesilesiyle gerçekleştirilmiştir. Bu çalışma kapsamında incelenen ve dört bloktan oluşması planlanan sitenin inşa edileceği saha Bursa ili, Mudanya ilçesinde yer almaktadır. Arazi düz ve engebesiz bir topoğrafyaya sahiptir. Toplam $64 \mathrm{~m}$ x $150 \mathrm{~m}$ büyüklüğünde bir sahada inşa edilecek olan blokların her biri 1 Bodrum kat, 1 Zemin kat ve 8 Normal kat olmak üzere toplam 10 katlı olup boyutları $18 \mathrm{~m}$ x $18 \mathrm{~m}$ olan oturma alanına sahip olacak şekilde planlanmıştır. Temel derinliği zemin yüzeyinden itibaren 4.0 m olarak tasarlanmıştır. İnceleme alanının uydu görüntüsü ve zemin araştırmalarını gösteren vaziyet planı Şekil 1'de verilmiştir.

\section{ARAZI ZEMIN MODELININ OLUŞTURULMASI}

Yönetmeliğin 16. Bölümü "Deprem Etkisi Altında Temel Zemini ve Temellerin Tasarımı İçin Özel Kurallar" başlığını taşımaktadır. İnşaat alanı zemin koşullarının tanımlanması, yapısal tasarım için gerekli geoteknik parametrelerin belirlenmesi ve raporlanması için yapılacak çalışmalar ve bunların kapsamı bu bölümde tarif edilmiştir. Bu bölümde yer alan önemli yeniliklerden birisi Zemin ve Temel Etüd Raporlarının zemin araştırmaları sonuçlarının sunulacağı Veri Raporu ve tasarıma yönelik olarak hazırlanacak olan Geoteknik Rapor'dan oluşacağının ifade edilmesidir. Veri Raporu, arazi ve laboratuvarda gerçekleştirilmiş zemin araştırmalarında elde edilen verilerin sunulduğu rapor olarak, Geoteknik Rapor ise statik, dinamik ve deprem etkileri göz önüne alınarak, arazi zemin modelinin oluşturulduğu, zemin tabakaları için geoteknik tasarım parametrelerinin verildiği, temel tipi seçimine ilişkin seçeneklerin irdelendiği, mühendislik analizleri ve değerlendirmeler ile temel tasarımına ilişkin önerilerin sunulduğu rapor olarak tanımlanmıştır.

Sahanın zemin modelinin ortaya konması için gereken zemin araştırmalarının kapsamının belirlenmesi aşamasında, başta yapımı planlanan inşaatın yapım sorumluluğunu üstlenen inşaat mühendisi ve arazi zemin modelinin ortaya konmasından ve yapı temel sistemi tasarımının gerçekleştirmesinden sorumlu geoteknik mühendisi olmak üzere ilgili disiplinlerin ortak çalışması asli unsurdur. Bu çalışma sonucunda, yapı ve bileşenlerinin 
özellikleri, jeolojik yapı ve zemin birimlerinin özellikleri, civar yapıların durumu, yeraltı suyu durumu ile bölgenin deprem özellikleri ve çevre koşulları dikkate alınarak uygun bir planlama yapılmış olacaktır. Bu planlama sonucunda sondaj kuyusu ve araştırma kuyularının konumları, sayı ve derinlikleri, hangi arazi deneylerinin yapılacağı ve bunların nicelikleri ve kapsamı ile yapılması gereken laboratuvar deneyleri ve bu deneyler için alınacak örselenmiş ve örselenmemiş örneklerin yeri ve sayısı belirlenmiş olacaktır. Zemin araştırmaları bağlamında göz önüne alınması gereken genel kurallar Ek 16A'da verilmiştir.

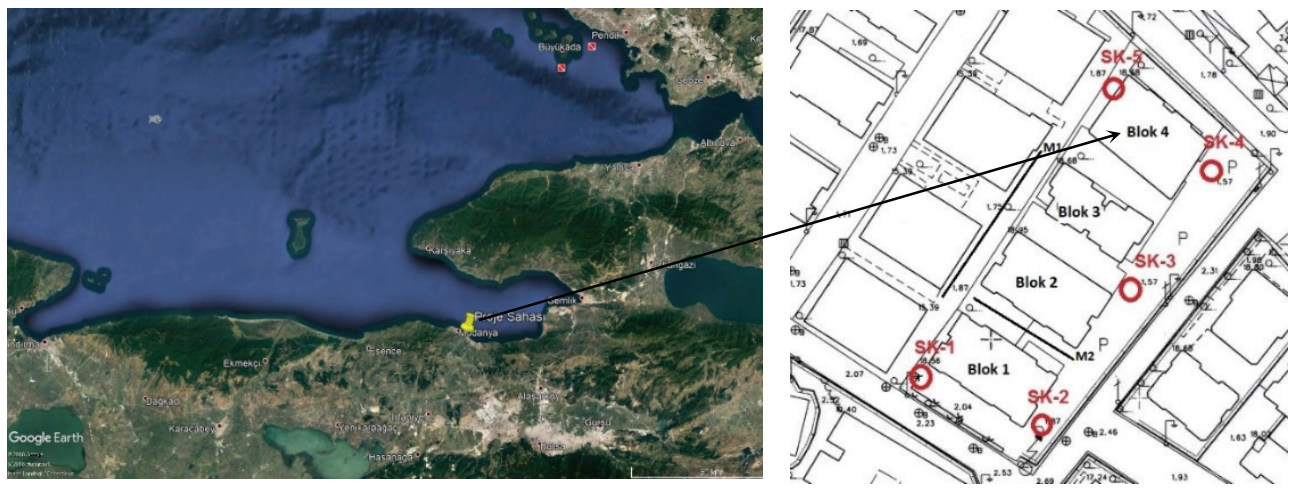

Şekil 1 - (a) Inceleme alanı uydu görüntüsü (Google Earth), (b) Vaziyet planı

\subsection{Zemin Araştırmaları}

Sahanın zemin modelinin ortaya konması kapsamında zemin profilinin ve bu profilde yer alan zeminlerin özelliklerinin belirlenmesine yönelik olarak inşası planlanan dört binanın yer aldığ parselde her biri $30 \mathrm{~m}$ derinlikte toplam 5 adet sondaj gerçekleştirilmiştir. TBDY2018'in yürürlüğe girdiği tarihten önce yapılan sondaj çalışmaları yeni Yönetmelikte Ek 16A'da sondajların sayısı, yerleri ve derinlikleri konusunda ifade edilen kurallarla büyük ölçüde uyum içindedir. Sondajların yanı sıra sahada iki serim yapılarak MASW (Çok Kanallı Yüzey Dalgası) analizleri gerçekleştirilmiş ve zemin profilinde sınırlı bir derinliğe kadar olan bir kesimde yer alan tabakaların kayma dalgası hızları belirlenmiş, iki noktada yapılan mikrotremor deneyleri ile de zemin hakim periyotları tespit edilmiştir. Sondajlar esnasında alınan örselenmiş ve örselenmemiş numuneler üzerinde sınıflandırma ve mukavemet deneyleri yapılmıştır. Zemin araştırmalarına başlanmasından önce veya araştırma esnasında etkileşimli planlamanın ve disiplinler arası ortak çalışmanın ne kadar önemli olduğu bu noktada bir kez daha vurgulanmalıdır. Yönetmelik ile zemin araştırmaları konusunda getirilen yeni kurallardan biri de Ek 16A.3.2'de ifade edildiği gibi sıvılaşma, şişme, göçme, yumuşama, hassas killer vb. sorunlu zeminlerde ilk 15 metre derinlikten alınan tüm örnekler üzerinde sınıflandırma deneylerinin yapılması zorunluluğudur. Bu noktanın ne kadar önemli olduğu bir sonraki sıvılaşma analizi bölümünde ortaya konacaktır.

$\mathrm{Bu}$ çalışmada inceleme alanındaki 4. Blok için tasarım gerçekleştirilmiş olup bu yapı için sonuçlar sunulmuştur. 4. Blok temel zemini SK-4 ve SK-5 sondajlarına göre belirlenmiştir. Arazi ve laboratuvar deney sonuçlarına göre zemin tabakalarına ait mukavemet parametreleri ve elastisite modülü değerleri sırasıyla Hatanaka ve Uchida [2] ile Kulhawy ve Mayne [3] tarafından önerilen bağıntılar kullanılarak tahmin edilmiştir (Şekil 2). Sahada yüzeyden 
itibaren yaklaşık $2 \mathrm{~m}$ kalınlığında dolgu tabakası, bunun altında sırasıyla kalınlığ $5-7 \mathrm{~m}$ arası değişen çakıllı kum, 10-12 m arası kalınlıkta orta sıkı kum, yaklaşık 6 m kalınlığında az killi sitli kum tabakaları ve sondajların nihayetlendiği çok ayrışmış kumtaşı tabakası yer almaktadır. Zemin profilinde yer alan farklı tabakalara ait kayma dalgası hızlarının belirlenmesi için, sahada yapılan MASW ölçümleri ve SPT deneylerinin sonuçlarına dayalı korelasyonlar kullanılmıştır. Wair vd. [4] tarafından çok sayıda korelasyon ilişkisi derlenerek önerilen ve düzeltilmiş $\mathrm{N}_{60}$ değeri ile düşey efektif gerilmenin dahil edildiği korelasyon ilişkileri göz önüne alınarak temel seviyesinden itibaren 30 metre derinliği kadar devam eden zemin profili için ortalama kayma dalgası hızı $\left(\mathrm{V}_{\mathrm{s}}\right)_{30} 190 \mathrm{~m} / \mathrm{s}$ olarak hesaplanmıştır.

\subsection{Yerel Zemin Sınıfı ve Tasarım Spektrumunun Belirlenmesi}

TBDY-2018'de yer alan en önemli yeniliklerden birisi tasarım spektrumlarının belirlenmesinde Türkiye Deprem Tehlike Haritalarının (TDTH) kullanılmasıdır. Bu şekilde, daha önceki deprem yönetmeliklerinde göz önüne alınan ve dört farklı derecede deprem bölgesinin ve buna karşılık gelen etkin ivme katsayısının, $A_{0}$, tanımlandığı Türkiye Deprem Bölgeleri Haritaları artık kullanılmayacaktır. Bir önceki yönetmelikte deprem yüklerinin belirlenmesinde esas alınan Spektral İvme Katsayısı, A(T), Etkin İvme Katsayısı ile Bina Önem Katsayısı, I, ve yerel zemin sınıfına bağlı Spektrum Katsayısı, S(T)'nin çarpımı sonucu belirlenmekte idi. TBDY-2018'de ise deprem yer hareketi spektrumunun belirlenmesi için Harita Spektral İvme Katsayısı ve Tasarım Spektral İvme Katsayısı olarak iki farklı kavram olarak tanımlanmıştır. Yönetmeliğe bağlı olarak gerçekleştirilen standart uygulamada deprem yer hareketi spektrumları, belirli bir deprem yer hareketi düzeyi esas alınarak $\% 5$ sönüm oranı için harita spektral ivme katsayılarına ve yerel zemin etki katsayılarına bağlı olarak belirlenecektir.

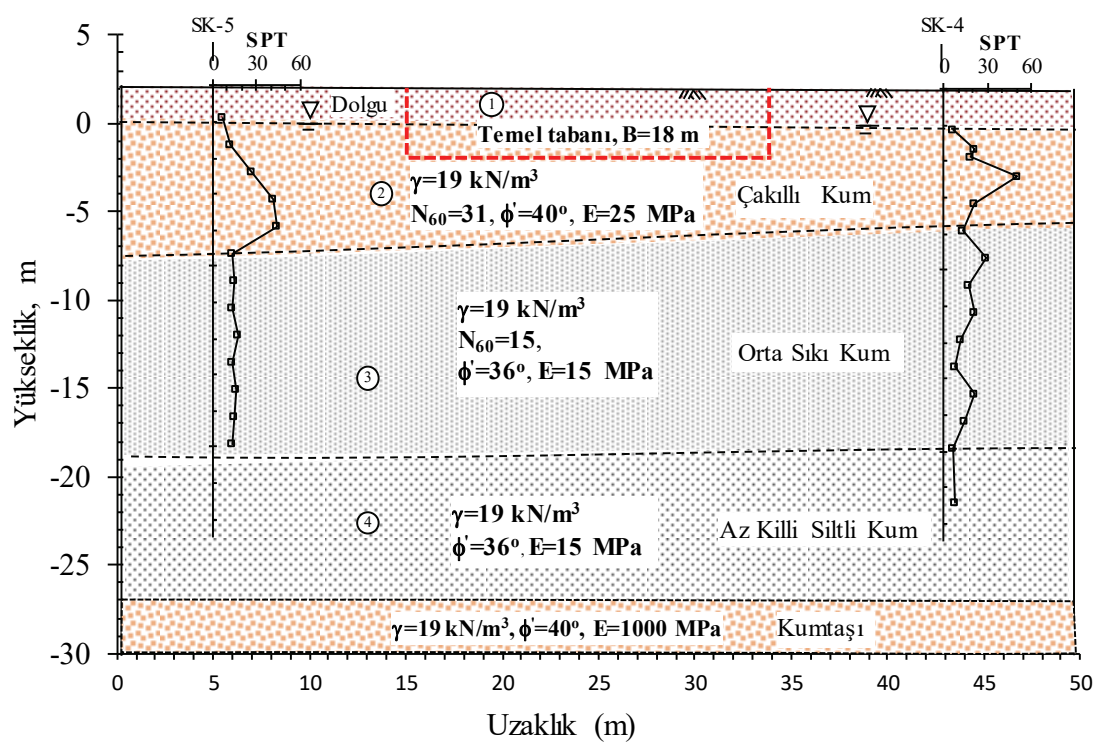

Şekil 2 - Inceleme alanına ait idealize zemin profili 
Harita spektral ivme katsayısı Türkiye Deprem Tehlike Haritaları (TDTH) kullanılarak belirlenecektir. TDTH çok sayıda bilim insanı tarafından yürütülen kapsamlı bir çalışma ile Türkiye ve yakın çevresinde meydana gelmiş olan aletsel dönem öncesi ve sonrası yüzlerce depremin ve ilgili çok sayıda deprem kataloğunun olasılıksal sismik tehlike hesaplamaları çerçevesinde değerlendirilmesi sonucunda hazırlanmıştır. Yönetmelikte tanımlanan dört farklı yer hareketi düzeyine bağlı olarak kayma dalgası hızı, $\left(\mathrm{V}_{\mathrm{s}}\right)_{30}=760 \mathrm{~m} / \mathrm{s}$ olan yüzeydeki jenerik kaya (mostra) için boyutsuz kısa periyot harita spektral ivme katsayısı, $\mathrm{S}_{\mathrm{s}}$ ve 1.0 saniye periyot için harita spektral ivme katsayısı $\mathrm{S}_{1}$, TDTH kullanılarak elde edilecektir. AFAD'a ait https://tdth.afad.gov.tr adresinde yer alan bu haritalara e-devlet üzerinden ulaşılabilmektedir. Deprem tehlike haritası verilerini elde etmek için öncelikle deprem yer hareketi düzeyine karar verilmesi gerekmektedir. Yönetmelikte, Kısım 2.2'de spektral büyüklüklerin 50 yıl içinde aşılma olasılığı düzeyine ve buna karşılık gelen tekrarlanma periyoduna bağlı olarak dört farklı deprem yer hareketi düzeyi tanımlanmıştır. Bu çalışmada ele alınan konut tipi yapılar için standart tasarım deprem yer hareketi olarak adlandırılan ve spektral büyüklüklerin 50 yılda bir aşılma olasılığının \%10 ve buna karşı gelen tekrarlanma periyodunun 475 y1l olduğu seyrek deprem yer hareketini ifade eden Deprem Yer Hareketi Düzeyi-2 (DD-2) göz önüne alınmıştır. Bu yer hareketi düzeyine uygun olarak inşaat sahasının yer aldığı konum için TDTH kullanılarak kısa periyot ve 1.0 saniye periyoduna ait harita spektral ivme katsayıları $\mathrm{S}_{\mathrm{S}}=0.943$ ve $\mathrm{S}_{1}=0.241$ olarak belirlenmiştir.

$\left(\mathrm{V}_{\mathrm{s}}\right)_{30}=760 \mathrm{~m} / \mathrm{s}$ olan mostra için belirlenen harita spektral ivme katsayıları kullanılarak yerel zemin etkisinin yansıtıldığı tasarım spektral ivme katsayılarının elde edilmesi için ilgili sahanın zemin profilini tanımlayan yerel zemin sınıfının belirlenmesi gerekmektedir. $\mathrm{S}_{\mathrm{S}}$ ve $\mathrm{S}_{1}$ değerlerinin tasarım spektral ivme katsayıları $\mathrm{S}_{\mathrm{DS}}$ ve $\mathrm{S}_{\mathrm{D} 1}$ 'e dönüştürülmesi için kullanılan yerel zemin etki katsayıları olan $F_{S}$ ve $F_{1}$ 'in tespiti için gerekli olan yerel zemin sınıflarının nasıl belirleneceği Yönetmelikte Kısım 16.4'te tarif edilmektedir. Sahada ve laboratuvarda gerçekleştirilecek zemin araştırmaları sonucunda zemin profilinin temel veya kazık başlığı alt kotundan itibaren aşağıya doğru en üst $30 \mathrm{~m}$ kalınlığındaki kısmı için belirlenecek olan ortalama kayma dalgası hızı, $\left(\mathrm{V}_{\mathrm{s}}\right)_{30}$, ortalama düzeltilmiş standart penetrasyon darbe sayısı $\left(\mathrm{N}_{60}\right)_{30}$ ve/veya ortalama drenajsız kayma dayanımı değerleri $\left(\mathrm{c}_{\mathrm{u}}\right)_{30}$ değerlendirilerek sahanın yerel zemin sınıfı tespit edilmektedir. Yönetmelikte ZA'dan ZF'ye kadar 6 farklı yerel zemin sınıfı tanımlanmış olup, ZF sahaya özel araştırma ve değerlendirme gerektiren zeminleri ifade etmektedir.

$\mathrm{Bu}$ çalışma kapsamında incelenen sahada yapılan zemin etüdü temel tabanı veya kazık başlığı alt kotundan itibaren $\left(N_{60}\right)_{30}=17$ ve $\left(\mathrm{V}_{\mathrm{s}}\right)_{30}=190 \mathrm{~m} / \mathrm{s}$ bulunmuştur. Bu değerlere göre inşaat alanının yerel zemin sınıfı ZD olarak belirlenmiştir. Yerel zemin etki katsayıları, yerel zemin sınıfı ile $S_{S}$ ve $S_{1}$ değerlerine bağlı olarak Tablo 2.1 ve Tablo 2.2 yardımıyla $F_{S}=1.123$ ve $\mathrm{F}_{1}=2.118$ olarak tespit edilmiş ve kısa periyot tasarım spektral ivme katsayısı, $\mathrm{S}_{\mathrm{DS}}=\mathrm{S}_{\mathrm{s}} \mathrm{F}_{\mathrm{s}}=1.059,1.0$ saniye periyodu tasarım spektral ivme katsayıs1, $\mathrm{S}_{\mathrm{D} 1}=\mathrm{S}_{1} \mathrm{~F}_{1}=0.510$ olarak hesaplanmıştır. $S_{D S}$ ve $S_{D 1}$ değerleri kullanılarak köşe periyotları $T_{A}$ ve $T_{B}$ ve yatay elastik tasarım spektral ivme değerleri hesaplanmış ve bu şekilde yatay elastik tasarım ivme spektrumu elde edilmiştir (Şekil 4). Yönetmeliğe uygun olarak sabit yerdeğiştirme bölgesine geçiş periyodu $T_{L}=6$ saniye alınmıştır. 


\section{DEPREM ETKİSI ALTINDA ZEMIN SIVILAŞMA RISKINININ DEĞERLENDİRILMESI}

Yönetmelikte Kısım 16.6'da hangi durumlarda sıvılaşma potansiyelinin araştırılacağı ifade edilmektedir. Buna göre, Deprem Tasarım Sınıfı DTS=1, DTS=1a, DTS=2 ve DTS=2a olan binalar için yerel zemin sınıfının ZD, ZE veya ZF olması halinde, sürekli bir tabaka veya kalın mercekler halinde bulunup Kısım 16.6.6'da tanımlanan durumlar dışında kalan kumlu zeminlerde sıvılaşma potansiyelinin bulunup bulunmadığının belirlenmesi zorunlu tutulmuştur. Burada tanımlanan muafiyet koşulları ise deprem tasarım sınıfının, DTS=4 olması durumunda kil içeriği \%20'den ve plastisite indisi \%10'dan büyük olan kumlu zeminler ile ince dane oranı \% 35'ten fazla ve düzeltilmiş SPT vuruş sayısı, $\mathrm{N}_{1,60}>20$ olan kumlu zeminlerdir. Yönetmelikte sıvılaşma analizinin SPT deneylerinin sonuçlarına dayalı olarak gerçekleştirilmesi için verilen yaklaşım basitleştirilmiş yönteme dayalı olarak Youd vd. [5] tarafından önerilen revizyonların ve ince dane oranı etkisi ile çevrimsel dayanım oranının formülleştirilmiş ifadelerinin göz önüne alındığı yöntemdir. Yönetmelikte sıvılaşma analizi için Koni Penetrasyon Deneyi (CPT) sonuçlarının veya kayma dalgası hızı değerlerinin kullanıldığg ve uygulamada genel kabul gören yöntemlerin de kullanılabileceği belirtilmiştir.

Sıvılaşmaya karşı güvenlik koşulu zeminin sıvılaşma direncinin zeminde deprem hareketi sebebiyle oluşan ortalama tekrarlı kayma gerilmesine oranının en az 1.10 olması koşulu olarak ifade edilmiştir. Sıvılaşma direncinin, $\tau_{R}$, hesaplanması için moment büyüklüğü $\mathrm{M}_{\mathrm{w}}=7.5$ olan depreme karşılık gelen çevrimsel dayanım oranı, $\mathrm{CRR}_{\mathrm{M} 7.5}$, değerinin belirlenmesi gerekmektedir. Bu değer ise ince dane içeriği göz önüne alınarak yeniden hesaplanmış $\mathrm{N}_{1,60 f}$ kullanılarak elde edilmektedir. Tasarım depremi moment büyüklüğünün 7.5'ten farklı olması durumunda deprem büyüklüğü düzeltme katsayısı, $\mathrm{C}_{M}$ 'nin kullanılması gerekmektedir. Zemin kayma gerilmesi hesabı için gereken en büyük yer ivmesi değeri ise kısa periyot tasarım spektral ivme katsayısının, $\mathrm{S}_{\mathrm{DS}}, \% 40$ '1 olarak alınacaktır. Ancak tasarım depremi büyüklüğünün nasıl belirleneceği konusunda yönetmelikte herhangi bir bilgi yer almamaktadır. Bu nedenle yönetmeliğin hazırlanması esnasında yararlanılan temel kaynaklar olan ASCE 7 [6] ve ilgili NEHRP [7] dökümanları incelenmiştir. Tavsiye Edilen Sismik Kurallar-NEHRP [7] kitapçığında sıvılaşma analizlerinde kullanılacak olan deprem büyüklüğünün deprem yer hareketinin belirlenmesinde göz önüne alınan afet seviyesi ile uyumlu olması gerektiği belirtilerek, yer hareketi hesaplamalarının olasılıksal sismik tehlike analizi sonucunda belirlenmesi durumunda deprem büyüklüğünün ayrıştırma (deaggregation) analizi yapılarak elde edilmesi gerektiği ifade edilmiştir. Ayrıştırma analizi sonucunda ilgili saha için olasılıksal olarak hesaplanan deprem tehlikesi, bu tehlikede payı olan tekil deprem kaynaklarına ayrıştırılarak tüm kaynakların büyüklük ve uzaklık cinsinden deprem tehlikesindeki bağıl katkısı belirlenmektedir. ABD'de deprem tehlikesi haritalarının kullanıcıların erişimine sunulduğu USGS' in ilgili sayfasında bu haritalara ait ayrıştırma analizi sonuçlarına da ulaşılabilmektedir. Ancak ülkemizde deprem tehlikesi haritalarının belirlenmesinde kullanılan deprem kataloğuna ait ayrıştırma analizleri yapılmamış durumdadır. Bu sebeple sıvılaşma analizi için gereken deprem büyüklüğünün tespiti için deterministik bir yaklaşım izlenerek proje sahası için deprem tehlikesine katkısı olan en büyük deprem, Akkar vd. [8] tarafından hazırlanan TDTH'de dikkate alınan deprem katalogları taranarak belirlenmiştir. Buna göre Marmara Üst Bölgesine (D) ait depremler ve deprem tekerrür modeli incelenerek, $\mathrm{M}_{\mathrm{w}}=7.5$ moment büyüklüğünün sıvılaşma analizlerinde kullanılmasının uygun olduğu sonucuna varılmıştır. Bu noktaya, sahaya özel zemin davranış 
analizi bağlamında belirlenen deprem kayıtlarının nasıl elde edildiğinin anlatıldığg dördüncü bölümde tekrar dönülecektir.

Bu çalışma kapsamında ele alınan binanın oturma alanı içinde yapılıış olan iki sondaja (SK4 ve SK5) ait düzeltilmiş ve ince dane oranı etkisine göre hesaplanmış $\mathrm{N}_{1,60 f}$ değerlerinin ve sıvılaşma analizi sonucunda hesaplanan sıvılaşmaya karşı güvenlik sayılarının zemin profili boyunca değişimleri Şekil 3'te, SK-4 sondajına göre detaylı sonuçlar Çizel 1'de verilmiştir. Çizelge 1'de sıvılaşma anındaki kayma gerilmesi oranını ifade eden CRR değeri TBDY 2018'de sunulan ve Youd vd. [5] tarafından verilen denklem ile hesaplanmıştır. Önerilen denklem $\mathrm{M}_{\mathrm{w}}=7.5$ moment büyüklüğü için geliştirilmiş olup, belirlenen deprem büyüklüğünün farklı olması durumunda hesaplanan CRR değerine bir düzeltme katsayısı uygulanmalıdır. Bu çalışmada deterministik yaklaşımla $\mathrm{M}_{\mathrm{w}}=7.5$ olarak belirlenmiş olup, ayrıştırma analizinin yapılması durumunda belirlenen deprem büyüklüğüne bağlı olarak sıvılaşmaya karşı güvenlik sayısının değişeceği vurgulanmalıdır. Efektif gerilme düzeltmesini ifade eden $\mathrm{K}_{\sigma}$ ise yönetmelikte bulunmamakla birlikte bu çalışmada hesaplara dahil edilmiştir. SK-4 ve SK-5 sondajlarındaki verilerle yapılan analiz sonuçlarına göre özellikle 5.0-23.0m derinlikleri arasındaki orta sıkı kum ve az siltli kum tabakalarında sıvılaşmaya karşı güvenlik sayıları 1.10'un altında elde edilmiştir. Bu sonuçlara göre zemin sınıfı ZF olarak belirlenmiş olup, deprem etkisi altında sahaya özgü zemin davranış analizlerinin doğrusal olmayan (nonlinear) zemin modelleri ile yapılması gerekmektedir. $\mathrm{Bu}$ analizler sonucunda sıvılaşma kaynaklı düşey yerdeğiştirmeler de belirlenmelidir.

Çizelge 1 - SK4 sondajı için yapılan zemin sıvılaşma değerlendirilmesi

\begin{tabular}{|c|c|c|c|c|c|c|c|c|c|c|c|c|}
\hline $\begin{array}{c}z \\
(m)\end{array}$ & $N_{60}$ & $\begin{array}{l}I D I \\
(\%)\end{array}$ & $\begin{array}{c}\sigma v \\
(k P a)\end{array}$ & $\begin{array}{c}\sigma_{v}^{\prime} \\
(k P a)\end{array}$ & $r_{d}$ & $C_{N}$ & $N_{1,60}$ & $N_{1,60, f}$ & CSR & $C R R$ & $\boldsymbol{K}_{\sigma}$ & $G S$ \\
\hline 2.3 & 7 & 11 & 42 & 37 & 0.982 & 1.64 & 11 & 13 & 0.306 & 0.136 & 1.00 & 0.44 \\
\hline 3.3 & 22 & & 62 & 47 & 0.975 & 1.45 & 31 & 31 & 0.353 & 0.609 & 1.00 & 1.72 \\
\hline 3.8 & 18 & 2 & 72 & 52 & 0.971 & 1.38 & 25 & 25 & 0.369 & 0.285 & 1.00 & 0.77 \\
\hline 4.8 & 51 & & 92 & 62 & 0.963 & 1.27 & 64 & 64 & 0.392 & 0.436 & 1.00 & 1.11 \\
\hline 6.3 & 21 & & 122 & 77 & 0.952 & 1.14 & 23 & 23 & 0.414 & 0.265 & 1.00 & 0.64 \\
\hline 7.8 & 14 & 1 & 152 & 92 & 0.940 & 1.04 & 14 & 14 & 0.426 & 0.151 & 1.00 & 0.35 \\
\hline 9.3 & 29 & & 182 & 107 & 0.926 & 0.96 & 28 & 28 & 0.432 & 0.378 & 0.99 & 0.86 \\
\hline 10.8 & 17 & 13 & 212 & 122 & 0.886 & 0.90 & 16 & 18 & 0.423 & 0.192 & 0.96 & 0.44 \\
\hline 12.3 & 22 & & 242 & 137 & 0.846 & 0.85 & 19 & 19 & 0.410 & 0.198 & 0.94 & 0.45 \\
\hline 13.8 & 11 & 5 & 272 & 152 & 0.806 & 0.81 & 9 & 9 & 0.396 & 0.105 & 0.92 & 0.24 \\
\hline 15.3 & 8 & 72 & 302 & 167 & 0.765 & 0.77 & 6 & 13 & 0.380 & 0.137 & 0.90 & 0.33 \\
\hline 16.8 & 21 & 6 & 332 & 182 & 0.725 & 0.74 & 16 & 16 & 0.363 & 0.167 & 0.89 & 0.41 \\
\hline 18.3 & 15 & 26 & 362 & 197 & 0.685 & 0.71 & 11 & 16 & 0.346 & 0.174 & 0.87 & 0.44 \\
\hline 19.8 & 7 & 21 & 392 & 212 & 0.645 & 0.66 & 4 & 9 & 0.328 & 0.101 & 0.86 & 0.27 \\
\hline 22.8 & 8 & 48 & 452 & 242 & 0.565 & 0.61 & 5 & 10 & 0.290 & 0.117 & 0.84 & 0.35 \\
\hline
\end{tabular}




\section{DEPREM ETKİSI ALTINDA SAHAYA ÖZEL ZEMIN DAVRANIŞ ANALIZLERI}

Yönetmeliğe göre sahaya özel zemin davranış analizleri, taban kayasında tanımlanan deprem yer hareketinin zemin tabakaları boyunca değişimini ve zemin yüzeyindeki deprem yer hareketini belirlemek üzere yapılır ve bina temeli ve yakın çevresinde zemin ortamının yaklaşık olarak yatay tabakalardan oluştuğu durumlarda, sahaya özel zemin davranış analizleri için tek boyutlu serbest zemin modeli kullanılabilir. Aksi durumda iki veya üç boyutlu zemin modelleri kullanılmalıdır. Sıvılaşma potansiyeli bulunan ZF sınıfı zeminlerde ise zaman tanım alanında doğrusal olmayan zemin davranış analizleri yapılması gerekmektedir. ASCE 7 [6] düşük periyotlu $(\mathrm{T}<0.5)$ yapıları istisna (exception) olarak değerlendirerek sahaya özel davranışın zorunlu olmadığını belirtmektedir. Ancak kazıklı temel sistemine sahip yapılarda yapı-kazık-zemin etkileşimi analizleri, zemin deformasyonlarının sahaya özel zemin davranış analizleri ile belirlenmesini zorunlu kılmaktadır. Bu konunun detayları Bölüm 6.2'de verilmiştir.
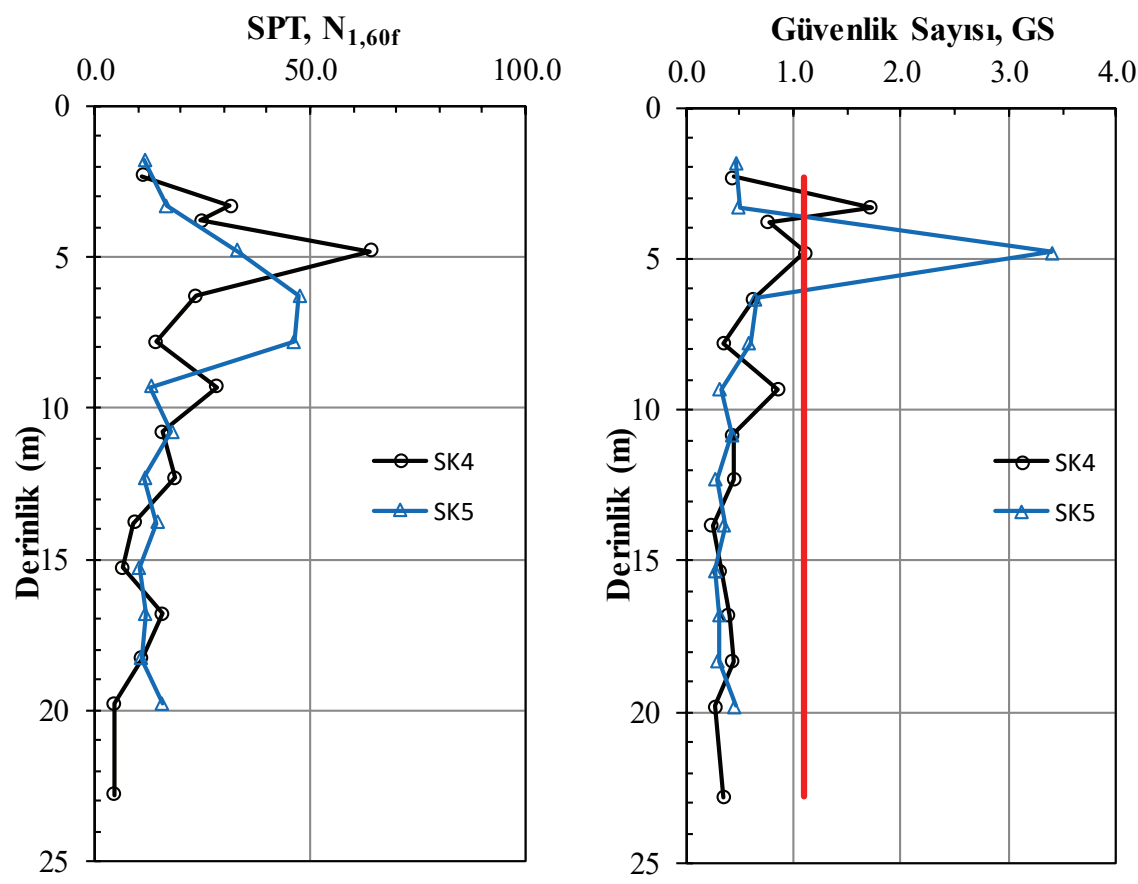

Şekil 3 - SK4 ve SK5 sondajlarına ait (a) SPT-N $N_{1,60 f}$ değerlerinin derinlikle değişimi ve (b) sıvılaşma analizi sonucunda bulunan güvenlik sayısının (GS) derinlikle değişimi

\subsection{Deprem Kayıtlarının Seçimi}

Sahaya özgü zemin davranış analizlerinde kullanmak üzere gereken en az on bir deprem kaydının TDTH'den elde edilen ve $\left(\mathrm{V}_{\mathrm{s}}\right)_{30}=760 \mathrm{~m} / \mathrm{s}$ için geçerli olan tasarım ivme spektrumu (Şekil 4) ile uyumlu olması gerekmektedir. Deprem kayıtlarının seçimi ve basit 
ölçeklendirme yöntemi ile ölçeklendirilmesi veya spektral uyuşum sağlanacak şekilde dönüştürülmesi için uygulanması gerekli kurallar TBDY 2018 Bölüm 2.5'te tanımlanmıştır. Buna göre, bir veya iki boyutlu hesap için seçilecek deprem kayıtlarının ve üç boyutlu hesap için seçilecek deprem kaydı takımlarının sayısı en az on bir olacak ve aynı depremden seçilecek kayıt veya kayıt takımı sayısı üçü geçmeyecektir. Deprem kayıtlarının seçimi, tasarıma esas deprem yer hareketi düzeyi ile uyumlu deprem büyüklükleri, fay uzaklıkları, kaynak mekanizmaları ve yerel zemin koşulları dikkate alınarak yapılacaktır. Binanın bulunduğu bölgede tasarıma esas deprem yer hareketi düzeyi ile uyumlu geçmiş deprem kayıtlarının mevcut olması durumunda öncelikle bu kayıtlar kullanılacaktır. Yönetmelikte bu noktada, sahaya özel deprem tehlikesine en fazla katkıda bulunan depremlere ait büyüklük ve fay uzaklığı bilgilerinin belirlenmesi için deprem tehlikesi ayrıştırma işleminden yararlanılabilir denmektedir (2.5.1.1). Ancak tasarım ivme spektrumunun belirlenmesi aşamasında yararlanılan TDTH'de kullanılmış olan deprem kayıtlarından oluşan verilerin tamamı ve göz önüne alınan modeller bilinmedikçe sahadaki deprem tehlikesine en fazla katkısı olan depremlerin belirlenmesine olanak verecek bir ayrıştırma analizi mümkün değildir. Bu noktada sahanın deprem tehlikesinde payı olan sismik kaynakların belirlenmesi amacıyla Akkar vd. [8] tarafından hazırlanmış olan Sismik Kaynakların Belirlenmesi ve Deprem Kataloğunun Derlenmesi raporunda verilen Türkiye anakarası üzerinde tanımlanan diri faylar ve bunların alt segmentlerine ait öznitelik bilgileri incelenerek şu sonuçlara ulaşılmıştır: Sahanın deprem tehlikesinde en büyük pay sahibi olan sismik kaynakların hepsi yanal atımlı olup Kuzey Anadolu Fay Zonu'nun (KAFZ) güney kolunda yer alan Gemlik fayının sahaya uzaklığı yaklaşık $5 \mathrm{~km}$ 'dir. Çok yakın mesafede Zeytinbağı ve Gençali fayları da mevcuttur. 11 deprem kaydı takımının 3 tanesinin bu özellikteki depremleri temsilen sahaya uzaklığı 0-10 km, deprem büyüklük aralığı $\mathrm{M}_{\mathrm{w}}=6.5-7.0$ olan depremlerin ivme-zaman kayıtlarının aranmasına karar verilmiştir. Sahaya $20-40 \mathrm{~km}$ mesafe içinde yer alan KAFZ Çınarcık segmenti ve Uluabat Fayı göz önüne alınarak $\mathrm{M}_{\mathrm{w}}=6.5-7.0$ aralığ 1 için 3 adet kayıt elde edilmiştir. Yaklaşık 45-70 km mesafede yer alan KAFZ'nun Kuzey kolunun Adalar segmenti ile Kumburgaz ve Avcılar segmenti ve bu mesafe aralı̆ğında kalan İznik-Mekece fayı için kataloglarda verilen en büyük değerler $\mathrm{M}_{\mathrm{w}}=7.0-7.2$ arasındadır. Bu mesafe ve $\mathrm{M}_{\mathrm{w}}=7.0-7.5$ aralığ 1 için 3 adet deprem kaydı aranmasının uygun olduğu anlaşılmıştır. Son olarak uzak kaynak kategorisinde Yenice-Gönen fayı dikkate alınarak 90-120 km mesafede ve $\mathrm{M}_{\mathrm{w}}=7.0-7.5$ aralığında depremlerden 2 kayıt seçilmiştir.

Deprem kayıtlarının belirlenmesinde yerel zemin koşullarına uygunluk bir diğer faktör olup, arama kriteri olarak sahanın zemin profiline ait $\mathrm{V}_{\mathrm{s} 30}$ değeri kullanılmaktadır. Ancak deprem büyüklüğü, fay uzaklığı, kaynak mekanizması ve yerel zemin koşullarının uyumlu olduğu deprem kayıtlarının belirlenmesinde en büyük zorluk yerel zemin koşuluna uygunluk kriterinin sağlanmasıdır. Bu sorunun aşılması için iki farklı çözüm yolu izlenebilir. İlk olarak, taban kayasının yüzeyde olmadığı bir sahada alınmış bir deprem kaydı, bu kaydın alındığ sahanın jenerik taban kaya seviyesine kadar zemin profilinin bilinmesi durumunda tersevrişim (de-convolution) ile taban kayaya taşınabilir ve daha sonra bu kayıt incelemeye esas olan sahanın taban kayasına uygulanıp zemin yüzeyine evrişim (convolution) ile taşınabilir. Ancak deprem kaydının alındığı istasyonlar arasında çok azının zemin profili belirlenmiş durumdadır ve bu yüzden bu seçenek ile az sayıda kayıt elde edilebilmektedir. Bu noktada ikinci bir seçenek ise arama kriteri olarak jenerik taban kaya üzerinde (mostra) alınmış deprem kayıtlarının kullanılmasıdır. Bu durumda bu kayıtlar ilgili sahada mostra (outcrop) olarak etkitilip evrişim ile zemin yüzeyine taşınabilmektedir. 
$\mathrm{Bu}$ çalışma kapsamında belirlenen arama kriterlerine uygun depremlere ait kuvvetli yer hareketi kayıtları için AFAD'ın ilgili sitesinde (deprem.gov.tr) ve PEER'a (Pacific Earthquake Engineering Research) ait https://ngawest2.berkeley.edu sitesinde [9] yer alan veri tabanları araştırılmıştır. Öncelikli olarak Mudanya ve çevresinde, daha sonra Türkiye anakarasında kriterlere uygun depremler aranmış ise de 11 deprem kaydı takımının tamamı PEER [9] veri tabanında bulunmuştur. Yönetmelik gereği olarak aynı depremden en fazla 3 farklı kayıt takımı alınmıştır. PEER veri tabanından alınan depremler, moment büyüklükleri $\left(\mathrm{M}_{\mathrm{w}}\right)$, kayıtların elde edildikleri istasyon, istasyonun faya olan uzaklığ $1\left(\mathrm{R}_{\mathrm{rup}}\right)$ ve istasyonun bulunduğu sahadaki $\left(\mathrm{V}_{\mathrm{s}}\right)_{30}$ değeri ile birlikte Çizelge 2'de verilmiştir. Kazıklı temellerin deprem hesabında kullanılmak üzere seçilen 11 adet deprem kaydının ivme spektrumlarının ortalamaları daha önce belirlenen elastik tasarım spektrumu ile spektral uyuşum sağlanacak şekilde ve tüm periyotlar için tasarım spektrumu ordinatlarından daha küçük olmayacak şekilde, TBDY 2018 Bölüm 2.5.3'te belirtildiği gibi dönüştürülüp RspMatch (GeoMotions, LLC) [10] programında ölçeklendirilmiştir. Belirlenen periyot aralığında yapılan ölçeklemede minimum periyot $0.02 \mathrm{~s}$, maksimum periyot ise $10 \mathrm{~s}$ olarak seçilmiştir. Bu yolla elde edilen ölçeklenmiş deprem kayıtlarının tepki spektrumları, ortalama spektrum ve tasarım spektrumu ile birlikte Şekil 4'te verilmiştir.

Çizelge 2 - Analizlerde kullanılan deprem kayıtları ve özellikleri

\begin{tabular}{|c|c|c|c|c|c|c|c|c|}
\hline $\begin{array}{c}\text { PEER } \\
\text { Kodu }\end{array}$ & Deprem & YIL & $\mathbf{M}_{\mathbf{w}}$ & İstasyon & $\begin{array}{c}\text { R }_{\text {rup }} \\
\text { (km) }\end{array}$ & $\begin{array}{l}\left(V_{s}\right)_{30} \\
(\mathrm{~m} / \mathrm{s})\end{array}$ & E-W & N-S \\
\hline RSN1108 & KOBE & 1995 & 6.90 & $\begin{array}{c}\text { Kobe } \\
\text { University }\end{array}$ & $\begin{array}{c}1 \\
(0-10)\end{array}$ & 1043 & DEP 1-1 & DEP 1-2 \\
\hline RSN1111 & KOBE & 1995 & 6.90 & $\begin{array}{l}\text { Nishi- } \\
\text { Akashi }\end{array}$ & $\begin{array}{c}7 \\
(0-10)\end{array}$ & 609 & DEP 2-1 & DEP 2-2 \\
\hline RSN1786 & HECTOR & 1999 & 7.13 & $\begin{array}{l}\text { Heart Bar- } \\
\text { State Park }\end{array}$ & $\begin{array}{c}61 \\
(45-70)\end{array}$ & 625 & DEP 3-1 & DEP 3-2 \\
\hline RSN1795 & HECTOR & 1999 & 7.13 & $\begin{array}{l}\text { Joshua } \\
\text { TreeN.M }\end{array}$ & $\begin{array}{c}50 \\
(45-70)\end{array}$ & 686 & DEP 4-1 & DEP 4-2 \\
\hline RSN1824 & HECTOR & 1999 & 7.13 & $\begin{array}{c}\text { San } \\
\text { Bernardino }\end{array}$ & $\begin{array}{c}96 \\
(90-120)\end{array}$ & 643 & DEP 5-1 & DEP 5-2 \\
\hline RSN3926 & TOTTORI & 2000 & 6.61 & OKYH08 & $\begin{array}{c}24 \\
(20-40)\end{array}$ & 694 & DEP 6-1 & DEP 6-2 \\
\hline RSN3932 & TOTTORI & 2000 & 6.61 & OKYH14 & $\begin{array}{c}26 \\
(20-40)\end{array}$ & 710 & DEP 7-1 & DEP 7-2 \\
\hline RSN3943 & TOTTORI & 2000 & 6.61 & SMN015 & $\begin{array}{c}9 \\
(0-10)\end{array}$ & 617 & DEP 8-1 & DEP 8-2 \\
\hline RSN6003 & SIERRA & 2010 & 7.20 & $\begin{array}{l}\text { Hinds } \\
\text { Plumbing- } \\
\text { Plant }\end{array}$ & $\begin{array}{c}116 \\
(90-120)\end{array}$ & 667 & DEP 9-1 & DEP 9-2 \\
\hline RSN6928 & DARFIELD & 2010 & 7.00 & LPCC & $\begin{array}{c}25 \\
(20-40)\end{array}$ & 650 & DEP 10-1 & DEP $10-2$ \\
\hline RSN6963 & DARFIELD & 2010 & 7.00 & $\mathrm{RPZ}$ & $\begin{array}{c}57 \\
(45-70)\end{array}$ & 638 & DEP 11-1 & DEP 11-2 \\
\hline
\end{tabular}




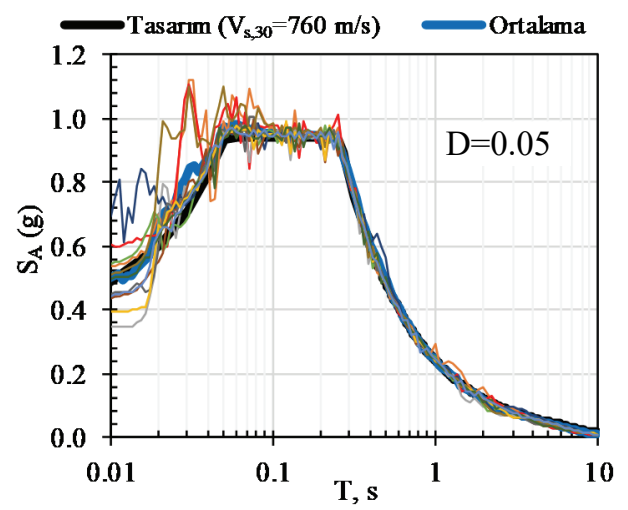

(a)

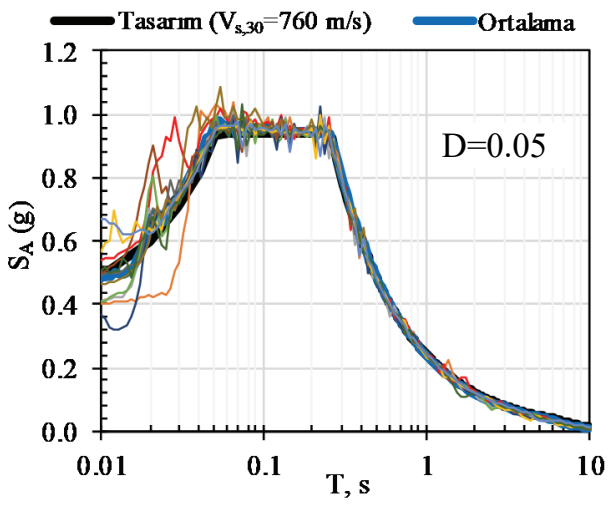

(b)

Şekil 4 - Tasarım spektrumuna ölçeklenmiş 11 adet deprem kaydının tepki spektrumları (a) Doğu-Batı doğrultusu, (b) Kuzey-Güney doğrultusu

\subsection{Zaman Tanım Alanında Yapılan Analizlerde Kullanılan Zemin Modeli}

Sahaya özel dinamik analizler Deepsoil [11] programında zaman tanım alanında yapılmıştır. Programda, temelleri Kondner ve Zelasko [12] tarafindan atılan ve Matasovic [13] tarafindan modifiye edilen hiperbolik model kullanılmıştır. Bu modelde, kayma gerilmesi ile kayma şekildeğiştirmesi arasındaki ilişki Denklem 1 ile verilen bağıntı ile kurulmaktadır.

$$
\tau=\frac{G_{m a k s} \gamma}{1+\beta\left(\frac{\gamma}{\gamma_{r}}\right)^{s}}
$$

Burada $\mathrm{G}_{\text {maks }}$ : maksimum kayma modülü, $\tau$ : kayma gerilmesi, $\gamma$ : kayma şekildeğiştirmesi ve $\gamma_{\mathrm{r}}$ : referans kayma şekildeğiştirmesi değeri olarak tanımlanırken, $\beta$ ve $\mathrm{s}$ ise kayma modülünün kayma şekildeğiştirmesine bağlı azalımını daha iyi ifade edebilmek için hiperbolik modele eklenen şekil parametreleridir. Denklem 1'de verilen bağıntıdaki maksimum kayma modülü, kayma dalgası hızı kullanılarak elastik bağıntı ile hesaplanmıştır $\left(\mathrm{G}_{\mathrm{maks}}=\rho \mathrm{V}_{\mathrm{s}}^{2}\right)$.

Kayma modülü ve sönüm oranı ile kayma şekildeğiştirmesi arasındaki ilişkinin, sahadan alınan zemin numuneleri üzerinde yapılacak laboratuvar deneyleri ile belirlenmesi gerekiyorken, çoğu zaman bu mümkün olmamaktadır ve zemin davranışını belirleyen gerilme-ş̧ekildeğiştirme eğrileri literatürden faydalanılarak belirlenmektedir. Bu çalışmada, Darendeli [14] tarafından geliştirilen ve derinlikle artan efektif gerilme etkisinin dikkate alınabildiği eğriler kullanılmıştır ve belirli derinliklerdeki gerilme-şekildeğiştirme eğrileri Şekil 5'te sunulmuştur.

Zaman tanım alanında yapılan dinamik serbest saha analizlerinde her bir zemin tabakasının iletebileceği maksimum frekans, kayma dalgası hızına ve tabaka kalınlığına bağlıdır $\left(f_{\text {maks }}=V_{s} / 4 \mathrm{H}\right)$. Bu çalışmada görece düşük kayma dalgası hızı değerine sahip tabakalara ait 
maksimum frekans değerini yüksek tutmak amacıyla $\left(f_{\text {maks }}>20 \mathrm{~Hz}\right) 30 \mathrm{~m}$ derinliğindeki zemin modeli toplam 16 alt tabakadan oluşturulmuştur. Hesap modelindeki parametreler Şekil 5'te verilen eğrilere uygun olacak şekilde belirlenmiştir ve Çizelge 3'te verilmiştir. Denklem 1 ile verilen bağıntı, monotonik yükler altındaki zemin davranışını ifade etmektedir. Çevrimsel yük altındaki davranış için ise yükleme-boşaltma davranışı tanımlanmalıdır. Çizelge 3 'te verilen $\mathrm{P}_{1}$ ve $\mathrm{P}_{2}$ değerleri Deepsoil [11] programında kayma modülü azalımı ve sönüm oranı değişiminin tanımlandığı gerilme-şekildeğiştirme eğrilerine uyum sağlayan ve yükleme-boşaltma ilişkisini belirleyen model parametreleridir.

Basitleştirilmiş yöntem ile yapılan analize göre zemin profilinde sıvılaşma potansiyeli taşıyan tabakalar mevcuttur. Bu sebeple zaman tanım alanında yapılan doğrusal olmayan dinamik analizde artık boşluk suyu basıncı oluşumunu dikkate alabilen bir model kullanılmalıdır. Bu amaçla Deepsoil [11] programında bulunan Dobry-Matasovic modeli kullanılmıştır. Ancak sahadaki zeminin sıvılaşma davranışı laboratuvar deneyleri ile belirlenmediği için boşluk suyu basıncı modelinde programın belirli bir saha için önerdiği parametreler ile analizler gerçekleştirilmiştir. Boşluk suyu basıncı parametrelerinin serbest saha analizi sonuçlarına etkisi, hassasiyet analizine benzer bir yöntemle farklı parametreler denenerek incelenmiştir. Özellikle daha sonra etkileşim analizlerinde kullanılacak olan serbest saha yerdeğiştirmeleri açısından, programın önerdiği parametrelerin kullanımının kayda değer bir fark yaratmadığ 1 gözlemlenmiştir.

Çizelge 3 - Sahaya Özgü Dinamik Zemin Davranış Analizi Model Parametreleri

\begin{tabular}{ccccccccc}
\hline \hline Zemin & $\mathbf{h}(\mathbf{m})$ & $\mathbf{V}_{\mathbf{s}}(\mathbf{m} / \mathbf{s})$ & $\mathbf{D}_{\text {min }}$ & $\gamma_{\text {ref }}$ & $\boldsymbol{\beta}$ & $\mathbf{s}$ & $\mathbf{P}_{\mathbf{1}}$ & $\mathbf{P}_{\mathbf{2}}$ \\
\hline Kum 1-1 & 1 & 105 & 1.78 & 0.0214 & 1.56 & 0.915 & 0.627 & 0.103 \\
\hline Kum 1-2 & 1 & 105 & 1.29 & 0.0330 & 1.635 & 0.915 & 0.629 & 0.104 \\
\hline Kum 1-3 & 2 & 157 & 1.05 & 0.0406 & 1.575 & 0.915 & 0.628 & 0.104 \\
\hline Çakıl 1-1 & 2 & 220 & 0.90 & 0.0462 & 1.5 & 0.915 & 0.628 & 0.104 \\
\hline Çakıl 1-2 & 2 & 220 & 0.82 & 0.0532 & 1.53 & 0.915 & 0.628 & 0.104 \\
\hline Kum 2-1 & 2 & 177 & 0.76 & 0.0600 & 1.575 & 0.915 & 0.628 & 0.104 \\
\hline Kum 2-2 & 2 & 177 & 0.72 & 0.0644 & 1.575 & 0.915 & 0.628 & 0.104 \\
\hline Kum 2-3 & 2 & 177 & 0.68 & 0.0640 & 1.485 & 0.915 & 0.628 & 0.104 \\
\hline Kum 2-4 & 2 & 177 & 0.65 & 0.0688 & 1.515 & 0.915 & 0.628 & 0.104 \\
\hline Kum 2-5 & 2 & 177 & 0.63 & 0.0742 & 1.56 & 0.915 & 0.628 & 0.104 \\
\hline Kum 2-6 & 2 & 177 & 0.61 & 0.0772 & 1.56 & 0.915 & 0.63 & 0.105 \\
\hline Kum 2-7 & 2 & 190 & 0.59 & 0.0774 & 1.515 & 0.915 & 0.63 & 0.105 \\
\hline Kum 2-8 & 2 & 190 & 0.58 & 0.0816 & 1.545 & 0.915 & 0.629 & 0.105 \\
\hline Kum 2-9 & 2 & 190 & 0.56 & 0.0858 & 1.575 & 0.915 & 0.629 & 0.105 \\
\hline Kum 2-10 & 2 & 190 & 0.55 & 0.0854 & 1.53 & 0.915 & 0.629 & 0.105 \\
\hline Kum 2-11 & 2 & 190 & 0.54 & 0.0866 & 1.515 & 0.915 & 0.629 & 0.105 \\
\hline \hline
\end{tabular}




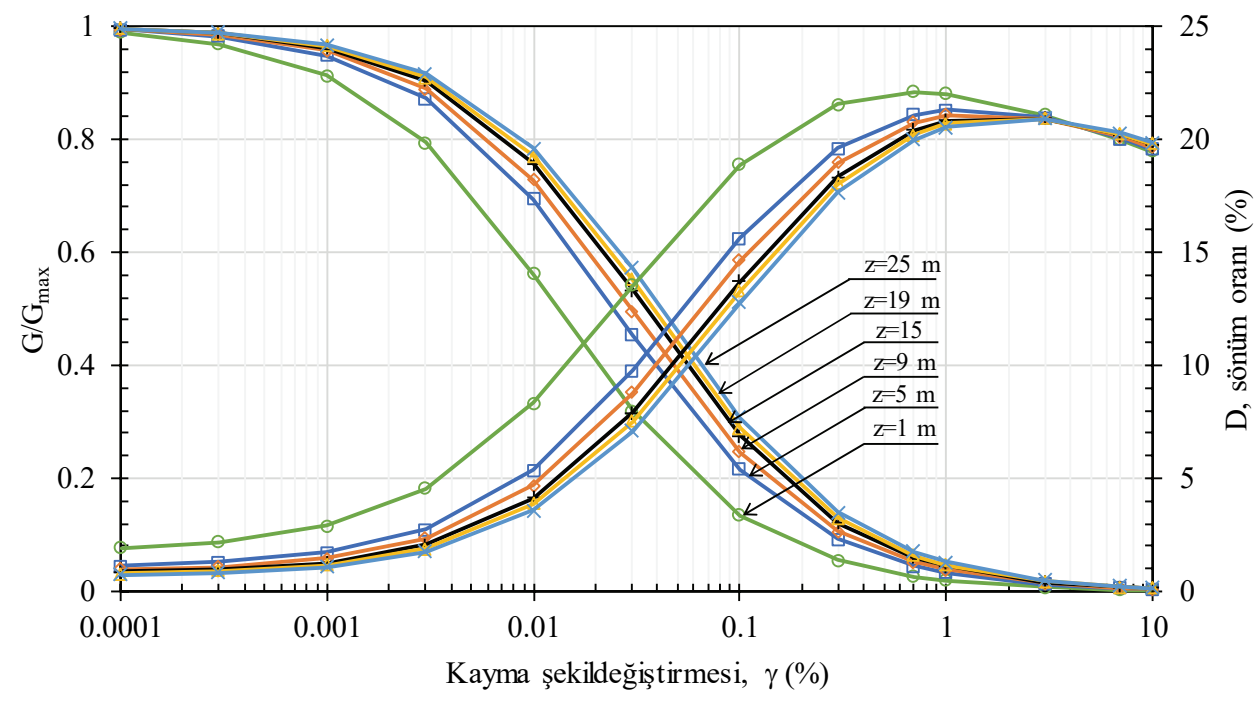

Şekil 5 - Analizlerde kullanılan normalize kayma modülü ve sönüm oranı ile kayma şekildeğiştirmesi ilişkisi (Darendeli [14])

\subsection{Serbest Saha Analizi Sonuçları}

Serbest saha analizleri sonucunda temel taban seviyesinde elde edilen ivme kayıtlarının tepki spektrumları Şekil 6'da yer almaktadır. Ayrıca, daha sonra zemin-yapı etkileşimi analizlerinde değerlendirilmek üzere, elde edilen yatay yerdeğiştirmeler ve kayma şekildeğiştirmelerinin derinlikle değişimi, sırasıyla Şekil 7 ve Şekil 8'de verilmiştir.

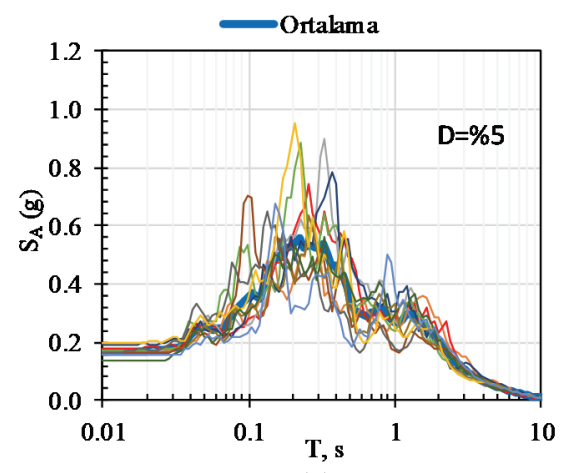

(a)

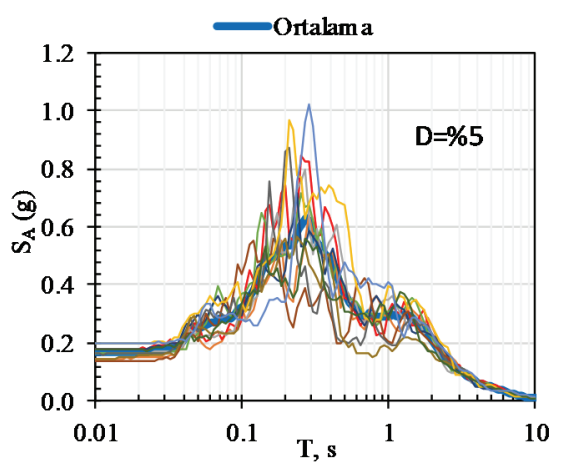

(b)

Şekil 6 - Serbest saha analizleri sonucunda temel tabanı seviyesinde elde edilen ivme kayıtlarına ait tepki spektrumları (a) D-B doğrultusu (b) $K$ - $G$ doğrultusu 


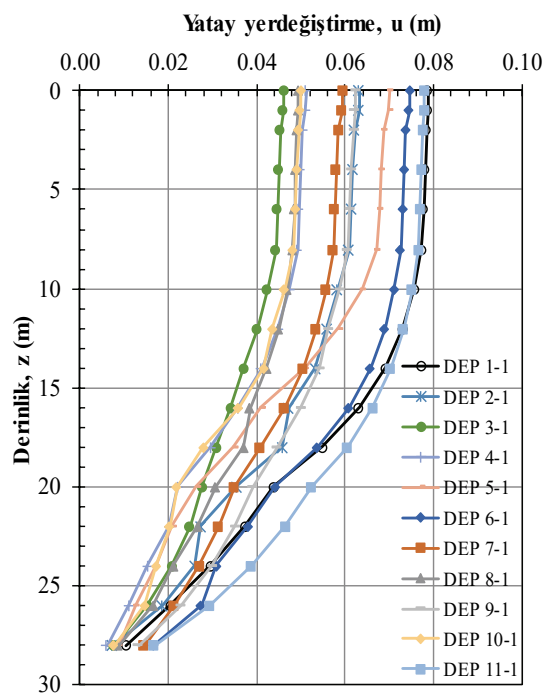

(a)

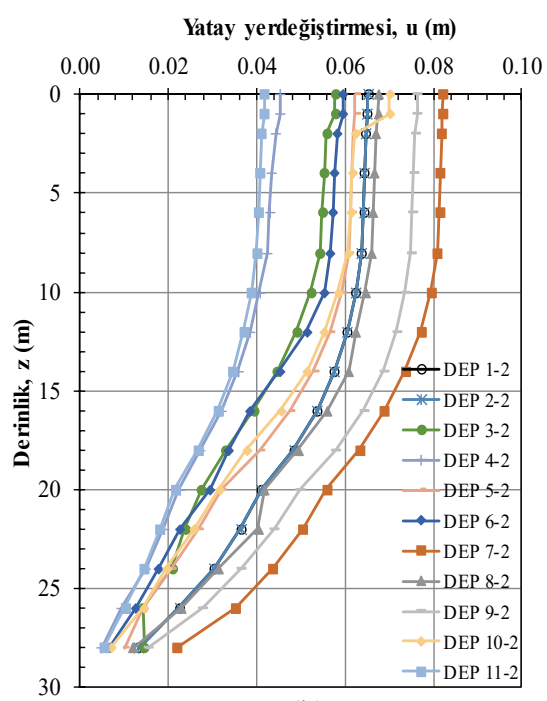

(b)

Şekil 7 - 11 adet deprem kaydı kullanılarak yapılan serbest saha analizlerinden elde edilen zeminin yatay yerdeğiştirmesinin derinlikle değişimi: (a) Kuzey-Güney doğrultusu (b) Doğu-Batı doğrultusu

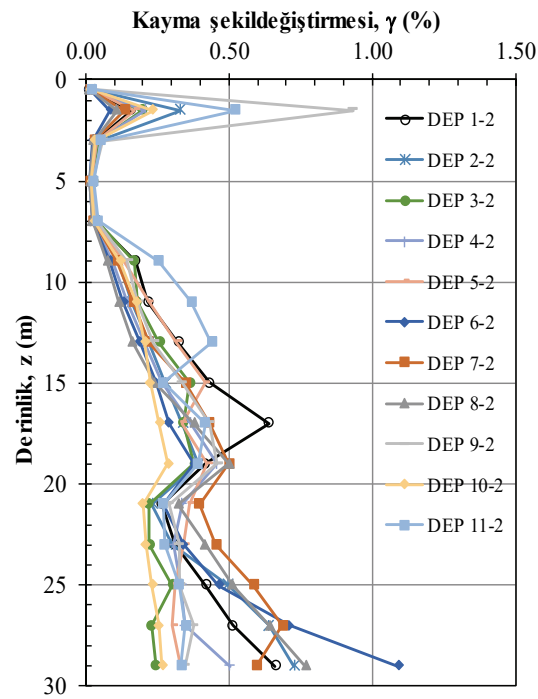

(a)

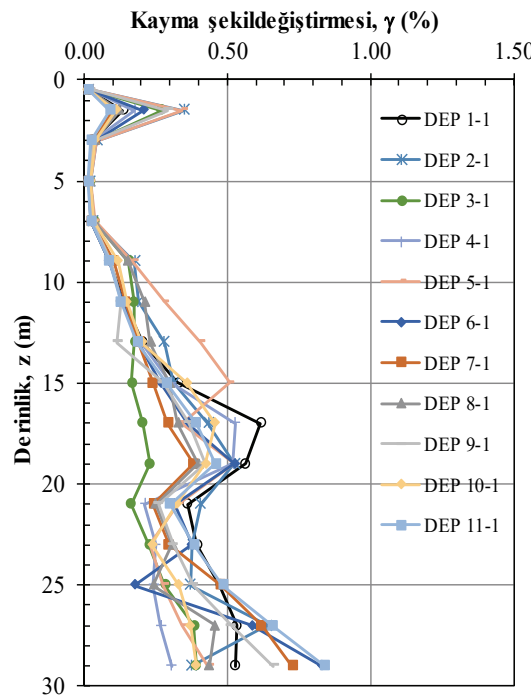

(b)

Şekil 8 - 11 adet deprem kaydı kullanılarak yapılan serbest saha analizlerinden elde edilen kayma şekildeğiştirmesinin derinlikle değişimi: (a) Kuzey-Güney doğrultusu (b) Doğu-Batı doğrultusu 


\section{SIVILAŞMA KAYNAKLI DÜŞEY YERDEĞİŞTIRMELERİN BELİRLENMESI}

TBDY 2018, Kısım 16.6.9'a göre sıvılaşma potansiyeli bulunan zemin tabakalarında sıvılaşma sonrası yerdeğiştirmelerin üstyapı-altyapı davranışına etkisi belirlenmelidir. $\mathrm{Bu}$ çalışmada sıvılaşma sonrasında, artık boşluk suyu basıncının sönümlenmesi ile oluşan düşey yerdeğiştirmelerin tahmini için Chiaradonna vd. [15] tarafından önerilen yaklaşım uygulanmıştır. Buna göre düşey yerdeğiştirme, artık boşluk suyu basıncının sönümlenmesi neticesinde artan düşey efektif gerilmenin $\left(\Delta \mathrm{u}=\Delta \sigma_{z}^{\prime}\right)$, hacimsel sıkışma modülüne ( $\left.\mathrm{E}_{\text {oed }}\right)$ bölünmesi ile belirlenen düşey şekildeğiştirmenin tabaka kalınlığı $(\Delta \mathrm{z})$ ile çarpılması sonucunda elde edilmektedir (Denklem 2).

$$
s=\sum_{i=1}^{N} \frac{\Delta \sigma_{z, i}^{\prime}}{E_{o e d, i}} \Delta z_{i}
$$

Yukarıda verilen denklemde bulunan $E_{o e d}$, kayma modülü $(G)$ ve Poisson oranı $\left(v^{\prime}\right)$ kullanılarak Denklem 3 ile hesaplanmıştır.

$$
E_{\text {oed }}=\frac{2 G\left(1-v^{\prime}\right)}{\left(1-2 v^{\prime}\right)}
$$

Kayma modülü sahaya özel zemin davranışı analizleri sonrasında her tabakada oluşan maksimum yatay şekildeğiştirmeye $(\gamma)$ bağlı olarak Denklem 1 ile bulunurken, $v^{\prime}=0.30$ kabul edilmiştir.

Serbest saha analizi sonuçlarına göre maksimum düşey yerdeğiştirme DEP 1-2 depreminde yaklaşık $7.8 \mathrm{~cm}$ olarak elde edilmiştir. Yapılan analizler sonucunda elde edilen kayma şekildeğiştirmesi, kayma modülü, hacimsel sıkışma modülü, artık boşluk suyu basıncı oranı ve düşey yerdeğiştirmelerin derinlikle değişimi Şekil 9'da verilmiştir. Ayrıca, Tokimatsu\&Seed [16], Ishihara\&Yoshimine [17], Shomato [18], Wu [19] ve Cetin vd. [20] yöntemleri kullanılarak toplam düşey yerdeğiştirmeler sırasıyla, $34 \mathrm{~cm}, 47 \mathrm{~cm}, 72 \mathrm{~cm}, 49 \mathrm{~cm}$ ve $13 \mathrm{~cm}$ olarak hesaplanmıştır. Yerdeğiştirmelerin derinlikle değişimi ise Şekil 10'da verilmiştir. Sonuç olarak, bulunan değerler birbirlerinden oldukça farklı olsa da, bütün yöntemlerde tahmin edilen yerdeğiştirmeler izin verilebilir sınırların üzerindedir (Eurocode 7'de [21] bu sınır $50 \mathrm{~mm}$ olarak belirtilmiş olup, TBDY 2018'de ise bu tür bir kriter verilmemiştir) ve bu zemin profilinin yüzeysel temel zemini olarak güvenli olmadığ1 kanaatine varılmıştır. Sahanın iyileştirilmesi veya derin temel sistemi ile yapı yüklerinin sıvılaşma potansiyeli olmayan tabakalara aktarımı önerilmiştir ve kazıklı temel sistemi tasarımı uygulanmıştır. 
TBDY 2018'e Göre Geoteknik Tasarım: Sıvılaşma ve Yapı-Kazık-Zemin ...
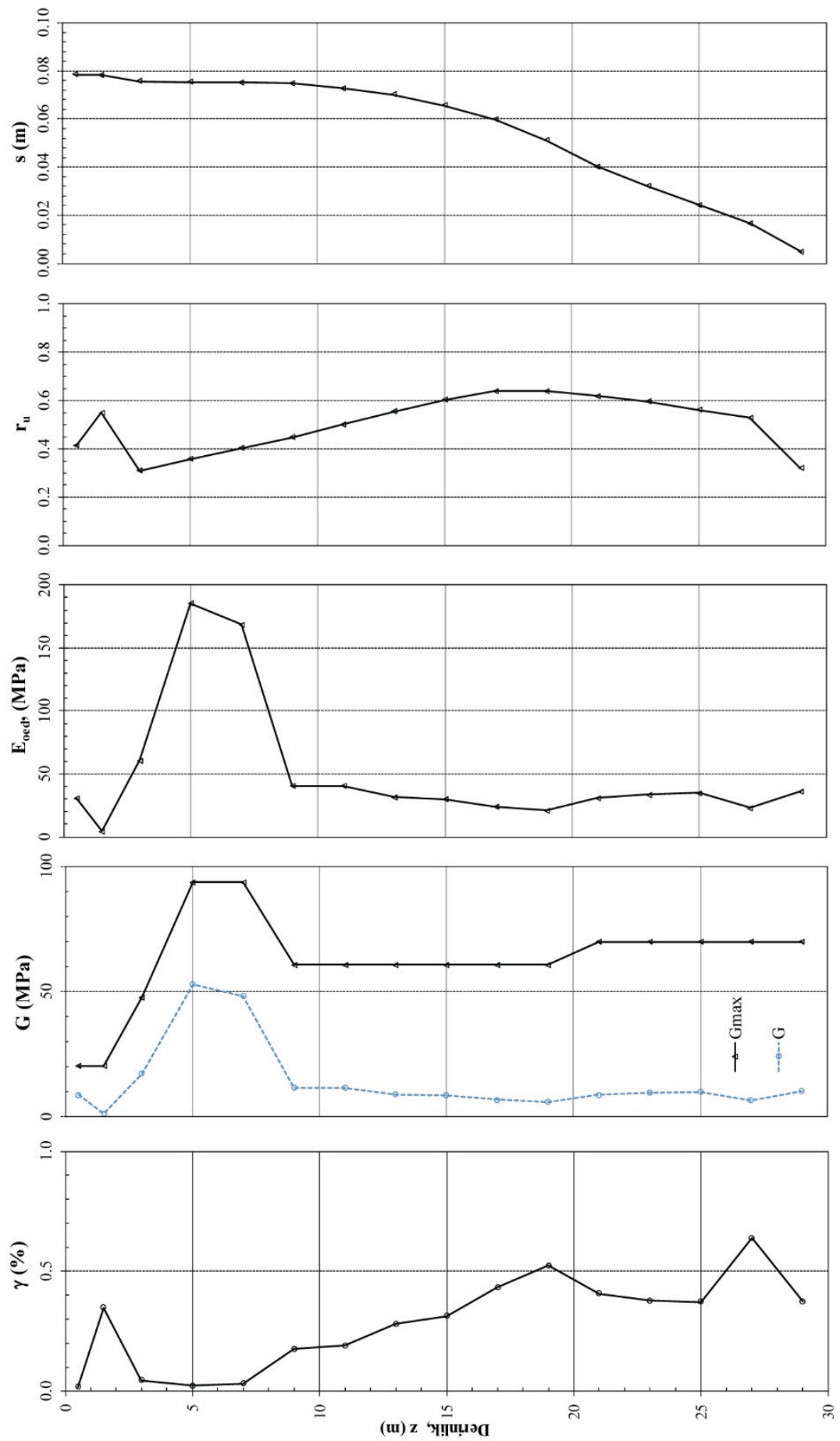

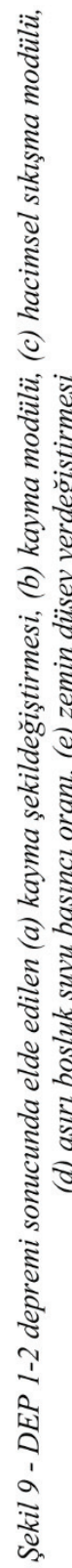




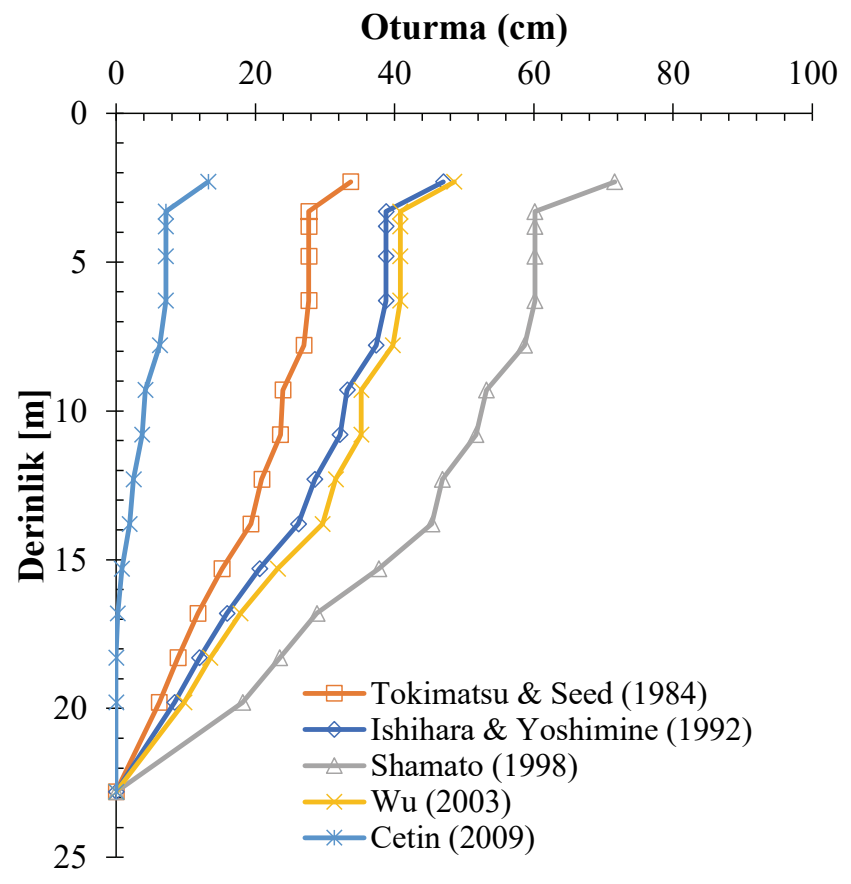

Şekil 10 - Sivllaşma kaynaklı düşey yerdeğiştirmelerin derinlikle değiş̧imi

\section{KAZIKLI TEMELLERIN TASARIMI}

\subsection{Düşey Yükler Altında Tasarım}

Derin temel sistemi seçeneği ile sıvılaşma potansiyeli yüksek olan sahada üstyapı yükünün kazıklar vasıtasıyla kumtaşı tabakasına aktarılması hedeflenmiştir. Bu sebeple kazıklı temel sisteminde kazık boyu ön tasarımda $\mathrm{L}=26.0 \mathrm{~m}$, kazık çapı ise $\mathrm{D}=1.0 \mathrm{~m}$ olarak seçilmiştir. Kazıklar arasındaki mesafe $4 \mathrm{~m}$ alınmıştır. Buna göre temel altında 25 adet $(5 \times 5)$ kazık tasarımı planlanmıştır.

Kazıklı temel tasarımında statik ve deprem etkisini içeren yükleme durumları için bir kazığın düşey tasarım kuvveti, $\mathrm{P}_{\mathrm{tv}}$, düş̧ey tasarım dayanımından, $\mathrm{Q}_{\mathrm{tv}}$, düşük olmalıdır. Tasarım dayanımı ise karakteristik dayanımın dayanım katsayılarına bölünmesi sonucu elde edilmektedir. Buna göre, düşey karakteristik dayanım, çevre sürtünmesi direnci ve uç direncinin toplanması sonucu literatürde kabul görmüş bağıntılara göre toplam 27370 kN olarak tahmin edilmiştir. Bir kazığa etkiyen statik düşey tasarım kuvveti, temelde oluşan maksimum gerilmenin $(224 \mathrm{kPa})$, etkili gerilme alanıyla $\left(4 \mathrm{~m} \mathrm{x} 4 \mathrm{~m}=16 \mathrm{~m}^{2}\right)$ çarpılması sonucu $3584 \mathrm{kN}$ bulunmuştur. Bu çalışmada statik yükler altında (1.4G+1.6Q yüklemesi) temel sisteminin kontrolü için güvenlik sayısı 3 olarak belirlendiği için kazıklı temel sistemi statik yükler ile yapılan hesaba göre güvenlidir. 


\subsection{Deprem Yükleri Altında Yapı-Kazık-Zemin Etkileşimi Analizleri}

Kazıklı temel sisteminin deprem hesabı için Yönetmelikte iki farklı hesap yaklaşımı verilmiştir. Ortak Sistem yaklaşımında üstyapı (bina), bina temeli, kazıklar ve zeminin taşıyıcı sisteminden oluşan tüm kısımların bir arada modellenip analiz edildiği doğrusal olmayan davranışları göz önüne alınabilmektedir. Bu çalışmada takip edilen Altsistem yaklaşımında ise üstyapı-temel altsistemi ile temel-kazık-zemin altsisteminin ayrı ayrı modellenip birbirleri ile etkileşimi de dikkate alınarak analiz yapılmaktadır. Altsistem yaklaşımında yapı-kazık-zemin etkileşimi Kinematik etkileşim ve Eylemsizlik etkileşimi olmak üzere iki aşamada ele alınmaktadır. Bu aşamalar için kullanılabilecek hesap yöntemleri Yöntem I, Yöntem II ve Yöntem III olarak adlandırılmış olup bu yöntemlerin uygulama alanları Deprem Tasarım Sınıfı (DTS), Bina Yükseklik Sınıfı (BYS) ve Yerel Zemin Sınıfına bağlı olarak Yönetmelikte tanımlanmıştır (Tablo 16.5). Yönetmelikte sunulan Tablo 3.1 ve 3.2'ye göre Deprem Düzeyi DD-2 için, kısa periyot spektral ivme katsayısı $\mathrm{S}_{\mathrm{DS}}$ $=1.059>0.75$ ve bina kullanım sınıfı BKS=3 için DTS=1 olarak belirlenmiştir. Tablo 3.3'e göre, DTS=1, BYS=4 (bina yüksekliği yaklaşık $30 \mathrm{~m}$ ) ve yerel zemin sınıfı ZF için Yöntem III'ün seçilmesi uygun bulunmuştur.

Bu çalışmada kazıklı temel sisteminin yapı-kazık-zemin etkileşimi analizleri SAP2000 [22] programında Yöntem III kullanılarak yapılmıştır. Kinematik etkileşim ve eylemsizlik etkileşimi olmak üzere başlıca iki aşamadan oluşan yöntemin hesap aşamaları şematik olarak Şekil14'de gösterilmiştir. Kinematik etkileşim, üstyapının kütlesinden bağımsız olarak serbest saha analizi sonucunda elde edilen zemin yerdeğiştirmelerinin kazıklarda oluşturacağı iç tesirleri ve temel tabanında elde edilen deprem kayıtlarını (etkin temel hareketi) kapsamaktadır. Eylemsizlik etkileşimi ise, üstyapı kütlesinin ivmelenmesi ile oluşan kuvvetin temel sistemine aktarılması olarak özetlenebilir. Buna göre etkileşim analizlerinin ilk aşaması, Şekil 14'de Girdi-1 olarak adlandırılan ve daha önce tepki spektrumları (Şekil 4) verilen deprem kayıtlarının elde edilmesidir. Yine detayları bir önceki bölümde açıklanan serbest saha analizi sonucunda elde edilen çıktılar ise zemin profili boyunca belirli derinliklerde elde edilen zemin yerdeğiştirmeleri (Çıktı-1.1, Şekil 7) ile temel taban seviyesindeki ivme kayıtlarına ait spektrumların ortalamasıdır (Çıktı-1.2, Şekil 6). Çıktı 1.1 kinematik etkileşim analizlerinde, Çıktı 1.2 ise eylemsizlik etkileşimi analizlerinde girdi olarak kullanılmaktadır.

TBDY 2018'e göre kinematik ve eylemsizlik etkileşimi analizlerinde kazıklar doğrusal (linear) davranış gösteren çubuk elemanlar olarak modellenmelidir. Kazık kütleleri eylemsizlik etkileşiminde hesaba dahil edilirken, kinematik etkileşiminde dikkate alınmayacaktır. Zemin davranışı ise dolaylı olarak, kinematik etkileşim analizlerinde doğrusal olmayan kuvvet-yerdeğiştirme ilişkileri (p-y eğrileri) ile, eylemsizlik etkileşiminde ise p-y eğrilerinin başlangıç rijitliği kullanılarak temsil edilmektedir. Bina temeli ve bodrum perdeleri ise kabuk elemanlar olarak modellenmektedir. Bina temeli kinematik etkileşim analizlerinde sonsuz rijit ve kütlesiz olarak modellenirken, eylemsizlik etkileşiminde kütleler göz önüne alınacaktır. Yöntem III'de kinematik etkileşim analizleri statik doğrusal olmayan (pushover), eylemsizlik etkileşimi analizleri ise statik doğrusal olarak yapılmalıdır. Yönetmeliğe uygun olarak SAP2000 [22] programında kurulan kazıklı temel ve üstyap1 modeli Şekil 11de verilirken, eylemsizlik ve kinematik etkileşim analizlerinin detayları Bölüm 6.2.1 ve 6.2.2'de açıklanmıştır. 


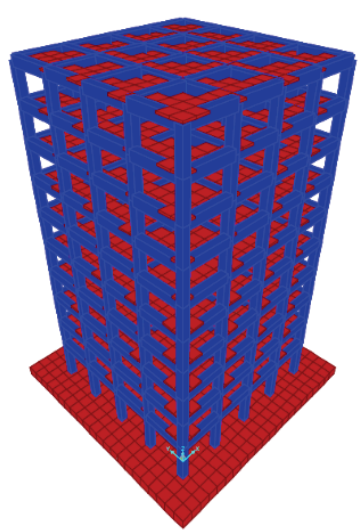

(a)

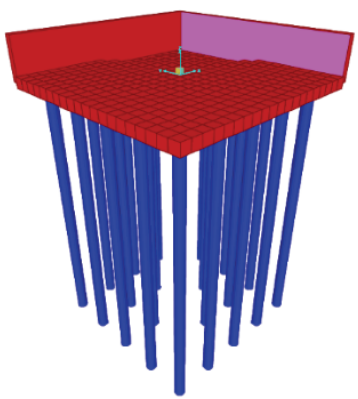

(b)

Şekil 11 - SAP2000 [22] programında kurulan (a) yapı ve (b) kazıklı temel sistemi modeli

\subsubsection{Kinematik Etkileşim Analizi}

Yöntem III'e göre kinematik etkileşim analizleri, serbest sahada elde edilen zemin yerdeğiştirmelerinin kazıklarda oluşturacağı iç tesirleri ve temel tabanındaki ortalama spektrumun belirlenmesini kapsamaktadır. Bir ucundan kazık düğ̈̈m noktasına bağlı olan py yaylarının öteki ucuna zemin yerdeğiştirmeleri uygulanarak kazık-zemin etkileşimi analizleri yapılmaktadır. Her bir deprem kaydı için elde edilen zemin yerdeğiştirmelerinin (Çıktı-1.1 ve Girdi-2, bkz. Şekil 14) kazıklara uygulanması sonucunda bulunan iç tesirlerin ortalaması ise Çıktı-2 olarak adlandırılmıştır.

Kum zeminde bulunan kazıkların yatay kuvvet-yerdeğiştirme davranışını temsil eden p-y eğrileri için, başlangıçta Reese vd. [23] tarafından önerilen bağıntının daha sonra API [24] tarafından geliştirilmesiyle elde edilen hiperbolik denklem kullanılmıştır. Şekil 12'de iki metre aralıklarla sunulan bu p-y eğrileri, yükün uygulama yönüne göre ön sıradaki kazıklarda kullanılmıştır. Grafikte p-y eğrileri çakıllı kum ve orta sıkı kum tabakası için ayrı ayrı verilmiştir. Kazık gruplarında gölgeleme etkisini dikkate alabilmek için, TBDY 2018'de yükün uygulama yönüne göre ön sıra kazıkların arkasında kalan kazıklarda verilen 16C.1 denklemi ile kuvvet (p) eksenine uygulan acak olan azaltma katsayısı hesaplanmıştır. Ön sıra dışında kalan kazıklar için, şekilde sunulan p-y eğrilerinin kuvvet (p) ekseni bu katsayı ile azaltılarak kullanılmıştır.

Yönetmelikte sıvılaşan zeminlerde bulunan kazıklarda kullanılacak p-y eğrileri hakkında bir ibare bulunmamaktadır. Literatürde bu konu hakkında birçok çalışma bulunmasına rağmen zemin-kazık davranışı henüz tam olarak anlaşılamamıştır. Ancak yaygın olarak kullanılan yöntem, sıvılaşma potansiyeli bulunan zeminlerde p-y eğrilerinin kuvvet (p) eksenine bir azaltma katsayısı (m) uygulanmasıdır. Bu katsayı için Brandenberg vd. [25] tarafından önerilen yaklaşım kullanılarak çakıllı kum tabakasında p ekseni 0.5 ile $\left(\mathrm{N}_{60}>24\right.$ için $\left.\mathrm{m}=0.5\right)$ ve orta sıkı kum tabakası için 0.2 ile $\left(\mathrm{N}_{60}>16\right.$ için $\left.\mathrm{m}=0.2\right)$ çarpılarak sıvılaşma durumunda zemin direncinde oluşacak kayıp dikkate alınmıştır.

TBDY 2018, 16C.4.2.1'e göre, kazık dügüum noktalarında zeminin düşey sürtünme direncini 
(t-z) ve uç direncini (Q-Z) temsil eden yayların kullanılması gerekmektedir. Ancak bu çalışmada kazıklar sıvılaşan zemin tabakalarından geçerek düşey yükü kazık ucunda kumtaşı tabakasına aktardığı için, hesap modelinde sıvılaşan zeminin düşey yönde kazık ile etkileşimini ihmal ederek t-z eğrileri hesaba katılmamış olup, kazık alt ucunda sınır koşulu olarak sabit mesnet kabul edilerek Q-Z yayları kullanılmamıştır. Ayrıca sıvılaşan zeminlerde t-z eğrileri için literatürde kabul görmüş bir yaklaşım bulunmaması sebebiyle düşey yöndeki kazık-zemin etkileşimi güvenli tarafta kalınarak ihmal edilmiştir.

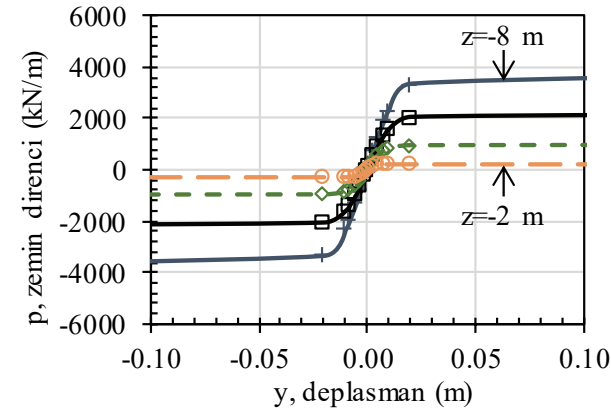

(a)

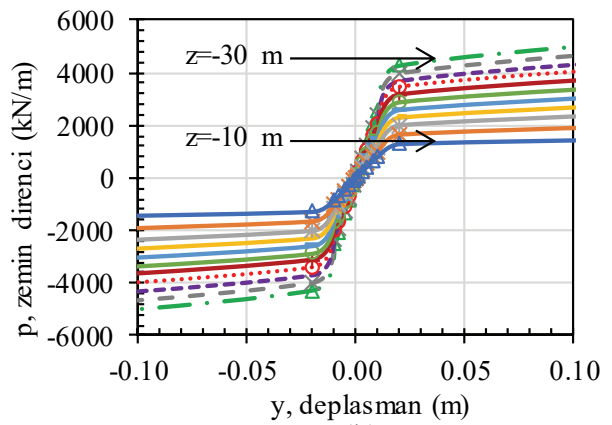

(b)

Şekil 12 - Yapı-kazık-zemin etkileşimi analizlerinde kullanılan p-y ĕgrileri (a) Çakıllı kum tabakası (b) Orta sıkı kum tabakası

Kinematik etkileşim analizleri SAP2000 [22] programı kullanılarak yapılmıştır. Kazıklı temel sisteminde oluşan yerdeğiştirmelerin örnek bir gösterimi DEP 1-1 ve DEP 1-2 yüklemeleri için Şekil 13'de verilmiştir. Analizler sonucunda her bir deprem için kazık boyunca bir yönde elde edilen en büyük moment, kesme kuvveti ve yatay yer değiştirmelerin ortalamaları kinematik etkileşim çıktıları (iç tesirler) olarak belirlenmiştir. Analizlerden elde edilen iç tesirler Bölüm 6.2.3’te sunulmuştur.

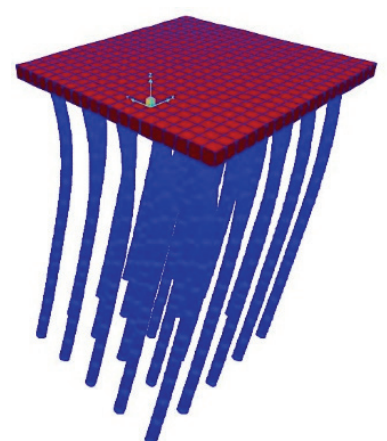

(a)

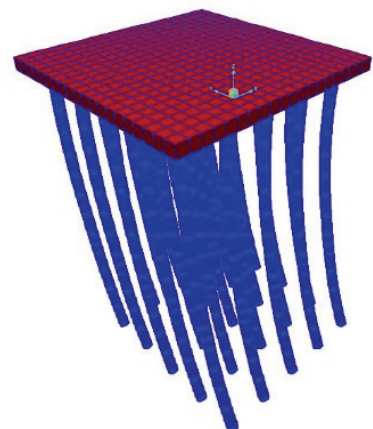

(b)

Şekil 13 - Kinematik analiz sonucunda kazlklı temel sisteminde meydana gelen yatay yer değiştirmeler

(a) DEP 1-1 yüklemesi (b) DEP 1-2 yüklemesi 


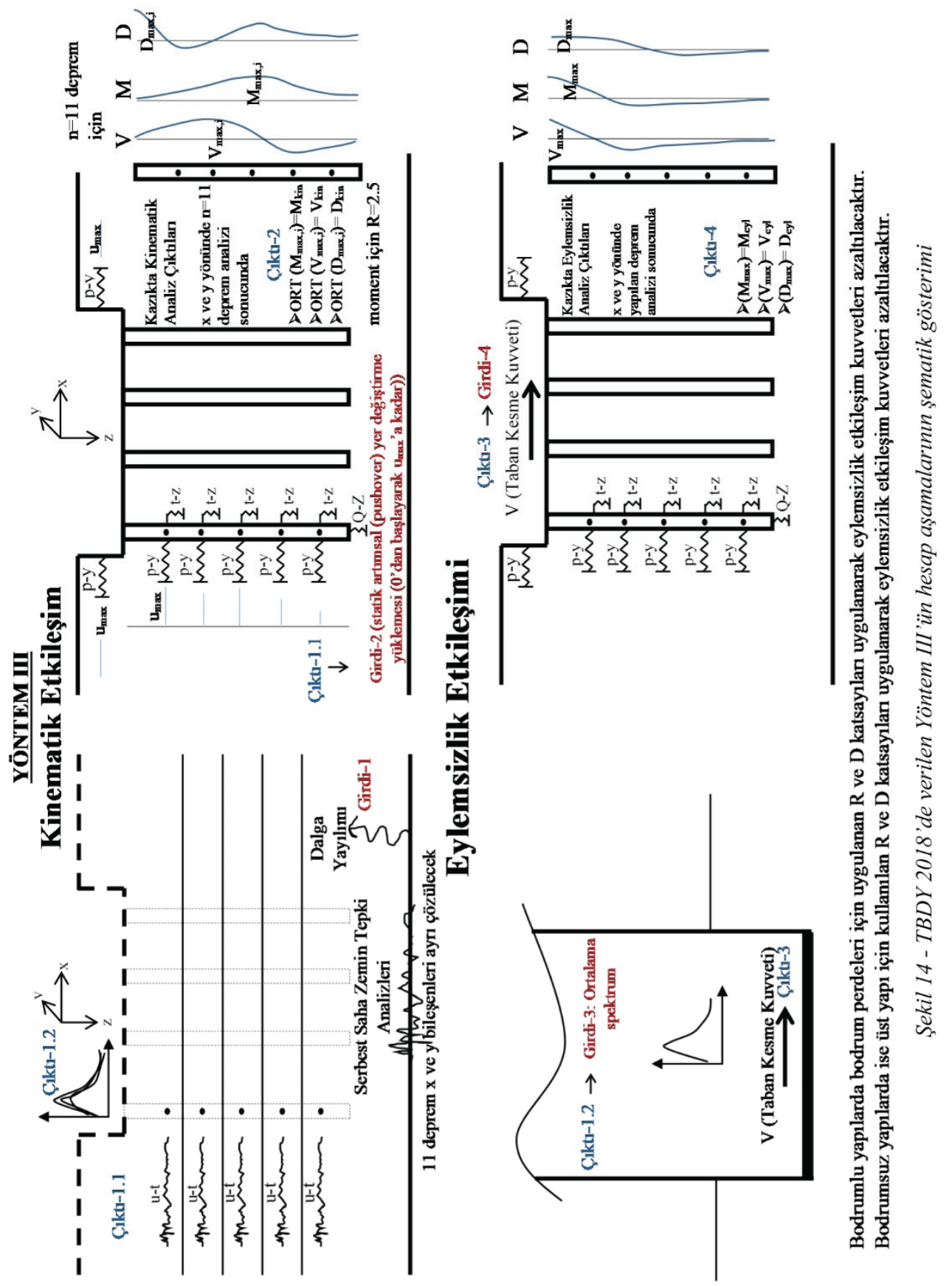




\subsubsection{Eylemsizlik Etkileșimi Analizi}

Eylemsizlik etkileşimi, üstyapı kütlesinin ivmelenmesi ile oluşan kuvvetin temel sistemine aktarılması olarak özetlenebilir. Yöntem III'e göre eylemsizlik etkileşiminin kazıklar üzerindeki etkisinin dikkate alınabilmesi için binanın tümüne etkiyen toplam eşdeğer deprem yükü (taban kesme kuvveti), kazıklı temel modeline uygulanmalıdır. Eylemsizlik etkileşimi analizlerinde kinematik etkileşim modelinden farklı olarak p-y eğrilerinin başlangıç rijitliği kullanıldığı için yükleme statik doğrusal analiz olarak yapılmalıdır. Taban kesme kuvvetini belirlemek için ise serbest saha analizleri sonucunda temel seviyesinde elde edilen ortalama spektrumlar (Şekil 6) değerlendirilmiştir (Girdi-3, bkz. Şekil 14). SAP2000 [22] programında kurulan üstyapı modelinde yapılan modal analiz sonucunda birinci mod periyodu yaklaşık 0.70 saniye olarak bulunmuştur ve taban kesme kuvveti bu periyoda karşılık gelen spektral ivme değerinin toplam yapı kütlesiyle çarpılması sonucu, $E_{x}=9381 \mathrm{kN}, E_{y}=9669 \mathrm{kN}$ olarak elde edilmiştir (Çıktı-3). Taban kesme kuvveti kazıklı temel modeline uygulanarak (Girdi-4) eylemsizlik analizi sonucunda en kritik kazıkta oluşan en büyük moment, kesme kuvveti ve yatay yerdeğiştirme değerleri belirlenmiştir (Çizelge 5). Bu çalışmada eylemsizlik etkileşim analizinden elde edilen kazık yatay yer değiştirmeleri kinematik analiz etkileşim sonucunda bulunan değerlere göre daha düşüktür.

\subsubsection{Kinematik Etkileşim ve Eylemsizlik Etkileşim Etkilerinin Birleştirilmesi}

Yapı-kazık-zemin etkileşimi analizleri sonucunda, kinematik ve eylemsizlik etkileşimi analizlerinden ayrı ayrı bulunan iç tesirler TBDY 2018, 16C.5 uyarınca birleştirilmelidir. Burada tasarıma esas iç tesirler, göz önüne alınan deprem doğrultusunda yapılan analiz sonucu elde edilen iç tesirler ile diğer yönde yapılan analiz sonucunda belirlenen iç tesirlerin \%30'unun toplanması sonucu (TBDY, 4.4.2) belirlenmelidir (Şekil 15). Kinematik ve eylemsizlik etkileşimi analizlerinde kazıklar doğrusal davranış gösteren çubuklar olarak ele alındığı için, kinematik etkileşim analizi sonucu bulunan eğilme momentleri davranış katsayısı $\mathrm{R}=2.5$ ile, eylemsizlik etkileşimi analizi sonucu bulunan iç tesirler ise bodrumlar için uygulanan davranış katsayısı olan $\mathrm{R}=1.5$ ile azaltılmıştır. Sonuçta, etkileşim analizlerinden elde edilen azaltılmamış ve tasarıma esas olacak azaltılmış iç tesirler ayrı ayrı Çizelge 5'de sunulmuştur.

$$
\begin{aligned}
& \text { Kazıkta Toplam Çıktılar } \\
& \text { x ve y yönünde } \\
& \text { - } \mathrm{M}_{\mathrm{x}}=\mathrm{M}_{\mathrm{x}, \text { kinematik }}+\mathrm{M}_{\mathrm{x}, \text { eylemsizlik }} \\
& \text { - } \mathrm{V}_{\mathrm{x}}=\mathrm{V}_{\mathrm{x}, \text { kinematik }}+\mathrm{V}_{\mathrm{x} \text {,eylemsizlik }} \\
& \text { - } \mathrm{D}_{\mathrm{x}}=\mathrm{D}_{\mathrm{x}, \text { kinematik }}+\mathrm{D}_{\mathrm{x}, \text { eylemsizlik }} \\
& \text { - } \mathrm{M}_{\mathrm{y}}=\mathrm{M}_{\mathrm{y}, \text { kinematik }}+\mathrm{M}_{\mathrm{y}, \text { eylemsizlik }} \\
& \text { - } \mathrm{V}_{\mathrm{y}}=\mathrm{V}_{\mathrm{y}, \text { kinematik }}+\mathrm{V}_{\mathrm{y}, \text { eylemsizlik }} \\
& \text { - } \mathrm{D}_{\mathrm{y}}=\mathrm{D}_{\mathrm{y}, \text { kinematik }}+\mathrm{D}_{\mathrm{y}, \text { eylemsizlik }}
\end{aligned}
$$

$\begin{array}{cc}\begin{array}{c}\text { Göz önüne alınan } \\ \text { doğrultu -x yönünde }\end{array} & \begin{array}{c}\text { Göz önüne alınan } \\ \text { doğrultu -y yönünde }\end{array} \\ \bullet \mathrm{M}_{\mathrm{T}}=\mathrm{M}_{\mathrm{x}}+0.3 \mathrm{M}_{\mathrm{y}} & \bullet \mathrm{M}_{\mathrm{T}}=\mathrm{M}_{\mathrm{y}}+0.3 \mathrm{M}_{\mathrm{x}} \\ \bullet \mathrm{V}_{\mathrm{T}}=\mathrm{V}_{\mathrm{x}}+0.3 \mathrm{~V}_{\mathrm{y}} & \bullet \mathrm{V}_{\mathrm{T}}=\mathrm{V}_{\mathrm{y}}+0.3 \mathrm{~V}_{\mathrm{x}} \\ \bullet \mathrm{D}_{\mathrm{T}}=\mathrm{D}_{\mathrm{x}}+0.3 \mathrm{D}_{\mathrm{y}} & \bullet \mathrm{D}_{\mathrm{T}}=\mathrm{D}_{\mathrm{y}}+0.3 \mathrm{D}_{\mathrm{x}}\end{array}$

Şekil 15 - Kinematik etkileşim ve eylemsizlik etkileşim etkilerinin birleştirilmesi 
$\mathrm{Bu}$ sonuçlara göre, kinematik etkileşim tesirlerinin eylemsizlik etkileşim tesirlerinden daha yüksek çıktığı görülmektedir. Bunun sebebi olarak, kinematik etkileşimde zeminin doğrusal olmayan davranış ile eylemsizlik etkileşiminde ise zeminin başlangıç rijitliklerini kullanarak doğrusal davranışla modellenmesi ve iç tesirlerin davranış katsayıları ile azaltılmış olması düşünülebilir. Analiz sonuçlarına göre en büyük tesirler X yönündeki deprem hareketi altında $\mathrm{M}_{\mathrm{T}}=1966 \mathrm{kN} . \mathrm{m}, \mathrm{V}_{\mathrm{T}}=2090 \mathrm{kN}$ ve yatay yer değiştirme, $\mathrm{D}=39 \mathrm{~mm}$ olarak elde edilmiştir. Kazık tasarımı bulunan bu en büyük tesirleri güvenli karşılayacak şekilde gerçekleştirilmelidir.

Çizelge 5 - Yapl-zemin etkileşimi analizleri sonucunda en kritik kazıkta oluşan maksimum eğilme momenti (M), kesme kuvveti (V) ve yerdeğiştirme (D) değerleri

\begin{tabular}{|c|c|c|c|c|c|c|c|}
\hline \multirow[b]{2}{*}{ Analiz } & \multirow[b]{2}{*}{ Yükleme Yönü } & \multicolumn{3}{|c|}{$\begin{array}{c}\text { Doğrusal Analiz } \\
\text { (Azaltılmamış Sonuçlar) }\end{array}$} & \multicolumn{3}{|c|}{$\begin{array}{c}\text { Davranış Katsayılarıyla } \\
\text { (Azaltılmış Sonuçlar) }\end{array}$} \\
\hline & & $\begin{array}{c}\text { M } \\
(\mathbf{k N . m})\end{array}$ & $\begin{array}{c}\mathrm{V} \\
(\mathbf{k N})\end{array}$ & $\begin{array}{c}D \\
(\mathrm{~mm})\end{array}$ & $\begin{array}{c}\text { M } \\
(\mathbf{k N} \cdot \mathbf{m})\end{array}$ & $\begin{array}{c}\mathrm{V} \\
(\mathrm{kN})\end{array}$ & $\begin{array}{c}\mathrm{D} \\
(\mathrm{mm})\end{array}$ \\
\hline \multirow{2}{*}{$\begin{array}{l}\text { Kinematik } \\
\text { Etkileşim }\end{array}$} & $(\mathrm{X})$ & 3446 & 1737 & 29.7 & 1378 & 1737 & 29.7 \\
\hline & $(\mathrm{Y})$ & 1609 & 664 & 25.5 & 643 & 664 & 25.5 \\
\hline \multirow{2}{*}{$\begin{array}{l}\text { Eylemsizlik } \\
\text { Etkileşim }\end{array}$} & $(\mathrm{X})$ & 451 & 176 & 1.6 & 301 & 117 & 1.1 \\
\hline & $(\mathrm{Y})$ & 472 & 183 & 1.6 & 315 & 122 & 1.1 \\
\hline \multirow{2}{*}{ Toplam } & $(\mathrm{X})$ & 3897 & 1913 & 31 & 1679 & 1854 & 30.8 \\
\hline & $(\mathrm{Y})$ & 2081 & 847 & 27 & 958 & 786 & 26.6 \\
\hline \multirow{2}{*}{$\begin{array}{l}\text { Birleştirilmiş } \\
\text { Toplam }\end{array}$} & $(\mathrm{X})$ & 4521 & 2167 & 39 & $\underline{1966}$ & $\underline{2090}$ & $\underline{39}$ \\
\hline & (Y) & 3250 & 1421 & 36 & 1461 & 1342 & 36 \\
\hline
\end{tabular}

\section{SONUÇLAR}

Bu çalışmada 1 Ocak 2019 tarihinde yürürlüğe girmiş olan TBDY-2018'e göre yapılan geoteknik tasarım bağlamında arazi zemin modelinin oluşturulması, sıvılaşma analizi ve yapı-zemin etkileşimi analizleri Bursa İli, Mudanya İlçesi'nde planlanan bir konut yapı inşaatı vakası kapsamında değerlendirilmiş olup tasarım detayları sunulmuştur. Zemin profilinde çakıllı kum ve orta sıkı kum tabakalarının bulunduğu bir sahada toplam 10 katlı bir bina yapımı planlanmıştır. Yerel zemin sınıfı ZD olan sahada sıvılaşma potansiyeli yeni yönetmeliğe göre incelenmiştir. Yapı temelinin oturacağı seviyeden itibaren yaklaşık 5-23 m derinlikleri arasında bulunan orta sıkı kum ve az siltli kum tabakalarında sıvılaşmaya karşı güvenlik sayıları 1.10'un altında elde edilmiştir. Bu nedenle, zemin sınıfı ZF olarak ele alınıp zaman tanım alanında doğrusal olmayan sahaya özel zemin davranış analizleri, hedef spektrumuna ölçeklendirilmiş 11 adet yer hareketi ivme-zaman kaydı kullanılarak gerçekleştirilmiştir. Sahaya özgü analizler sonucunda tespit edilen sıvılaşmaya bağlı zemin yerdeğiştirmelerinin üstyapı için izin verilen sınır değerlerin üzerinde olması sebebiyle derin (kazıklı) temel sistemine karar verilmiştir. Kazıklı temelin ön boyutlandırılması yapıldıktan sonra üst yapıdan gelen statik ve dinamik yükler altındaki düşey kapasitesi ve yatay deprem 
yükler altındaki davranışı incelenmiştir. Yönetmelikte kazıklı temel sistemi analizi için bina yüksekliğine ve bölgenin depremselliğine bağlı olarak uygulanabilecek üç yöntem önerilmiştir. Bu vakada, yapı-kazık-zemin etkileşimi analizleri kinematik etkileşim ve eylemsizlik etkileşim olmak üzere iki alt bileşene ayrılarak ve yeni yönetmelikte Yöntem III olarak adlandırılan yaklaşıma göre yapılmıştır. Kinematik etkileşim analizlerinde kazık boyunca belirli seviyelerdeki düğüm noktalarına yerdeğiştirme yüklemesi yapılmıştır. Yapıkazık-zemin etkileşimi analizleri için seçilen 11 adet deprem kaydı kullanılarak sahaya özel zemin davranış analizleri DeepSoil v.7 [11] programı kullanılarak gerçekleştirilmiştir. Düğüm noktalarındaki yerdeğiştirmeler ise zemin davranış analizleri sonuçlarından elde edilmiştir. Zeminin uygulanan yatay yerdeğiştirme yüklemesine karşı direnci ise yine yönetmelikte önerilen doğrusal olmayan p-y yayları ile dikkate alınmıştır. Eylemsizlik etkileşiminde ise zemin davranış analizleri ile temel altı seviyesinde elde edilen spektrumlar kullanılmıştır. Son olarak eylemsizlik etkileşimi ve kinematik etkileşim analizlerinden elde edilen kesit tesirleri birleştirilerek kazıklı temel sisteminde oluşacak en büyük tesirler belirlenmiştir. $\mathrm{Bu}$ aşamada, elde edilen sonuçların yönetmelikte etkileşim analizleri için önerilen en sade yöntemin (Yöntem III) kabulleriyle doğrudan ilişkili olduğu belirtilmelidir. Aynı sistemin daha detaylı olduğu bilinen diğer yöntemler ile çözülerek analiz sonuçlarının başka bir çalışma kapsamında karşılaştırılması gerekmektedir.

TBDY-2018, kendisinden önceki yönetmeliklere göre önemli yenilikler getirmektedir. Ancak, bu çalışmaya konu olan vaka analizi bağlamında yapılan hesaplamalar esnasında Yönetmeliğin bazı noktalarda geliştirilmesi gerektiği düşünülmektedir. Binaların deprem etkisi altında tasarımında esas alınacak deprem yer hareketlerine ilişkin verilerin 22/01/2018 tarih ve 2018/11275 sayılı Bakanlar Kurulu kararı ile yürürlüğe giren Türkiye Deprem Tehlike Haritaları ile tanımlanmış olması getirilen yeniliklerin başlıcasıdır. Bu şekilde belirli bir saha için deprem yer hareketi spektrumunun elde edilmesi oldukça kolaylaşmış olsa da, bu sahadaki deprem tehlikesini oluşturan farklı deprem kaynaklarının bu deprem tehlikesi içindeki ağırlıklarını ortaya koyan ayrıştırma analizi (deaggregation) sonuçlarına ulaşılamamaktadır. Halbuki, binaların deprem hesabında kullanılacak deprem kayıtlarının seçiminde ve sıvılaşma esnasında kullanılan temel verilerden birisi olan deprem büyüklüğünün belirlenmesi için ayrıştırma analizi sonuçlarına ihtiyaç vardır.

Sahaya özgü analiz yapılması durumunda gereken 11 adet deprem kaydı takımının elde edilmesi aşaması ise bir başka sorunlu noktadır. Deprem kayıtlarının tasarıma esas deprem yer hareketi düzeyi ile uyumlu olacak şekilde ve deprem büyüklüğü, fay uzaklı̆̆ı, kaynak mekanizmaları ve yerel zemin koşulları dikkate alınarak bulunması veya yeterli sayı veya nitelikte deprem kaydının elde edilememesi halinde zaman tanım alanında benzeştirilmiş (sentetik) deprem kayıtları kullanılması gerekmektedir. Bu şekilde belirlenen kayıtların spektrumlarının ortalamaları, tüm periyotlar için tasarım spektrumu ordinatlarından daha küçük olmayacak şekilde ölçeklendirilmelidir. Bu bağlamda uygulamada zorluklarla karşılaşılması muhtemeldir. Herhangi bir noktadaki deprem kaydını belirleyen değişkenlerin çokluğu ve karmaşıklığı düşünüldüğünde, en az 11 adet deprem kaydının bir tasarım zarfına ölçeklenme süreci oldukça sıkıntılı olmaktadır. Ülkemizde ve dünya üzerindeki kuvvetli yer hareketi kayıtlarının sayısı arttıkça bu zorluk azalacaktır. Bunların yanı sıra temel zemininde oluşan oturmalar için Yönetmelikte sınır değerlerinin belirtilmemiş olması ve yapı-kazıkzemin etkileşimi bağlamında kinematik ve eylemsizlik yaklaşımlarında farklı davranış kabullerinin söz konusu olması bu çalışmada dile getirilen ve tartışılan diğer sorunlardır. 


\section{Semboller}

B Temel genişliği

BYS Bina yükseklik sınıfı

$\mathrm{C}_{\mathrm{M}} \quad$ Deprem büyüklüğü düzeltme katsayısı

CPT Koni penetrasyon deneyi

$\mathrm{CRR}_{\mathrm{M} 7.5}$ Çevrimsel dayanım oranı

$\mathrm{c}_{\mathrm{u}} \quad$ Drenajsiz kayma dayanımı

$\left(\mathrm{c}_{\mathrm{u}}\right)_{30} \quad$ Temel tabanından itibaren 30 metre derinliğe kadarki ortalama drenajsız kayma dayanımı

D Kazık çapı, kazık iç tesiri (yerdeğiştirme) ve sönüm oranı

DD Deprem düzeyi

DTS Deprem tasarım sinıfi

E Deformasyon modülü

E Hacimsel sıkışma modülü

$\mathrm{E}_{\mathrm{t}} \quad$ Tasarım etkileri

$\mathrm{F}_{\mathrm{S}} \quad$ Kısa periyot bölgesi için yerel zemin etki katsayısı

$\mathrm{F}_{1} \quad 1.0$ saniye periyot için yerel zemin etki katsayısı

$\mathrm{f}_{\text {maks }} \quad$ Maksimum frekans

G Sabit yük

$\mathrm{G}_{\text {maks }} \quad$ Maksimum kayma modülü

$\mathrm{H} \quad$ Zemin tabakası kalınlığ

KAFZ Kuzey Anadolu fay zonu

$\mathrm{K}_{\sigma} \quad$ Efektif gerilme düzeltmesi

L Kazık boyu

M Eğilme momenti

$\mathrm{M}_{\mathrm{w}} \quad$ Moment büyüklüğü

$\mathrm{m} \quad$ Zemin direnci azaltma katsayısı

$\mathrm{N}_{60} \quad$ Düzeltilmiş SPT değeri

$\left(\mathrm{N}_{60}\right)_{30} \quad$ Temel tabanından itibaren 30 metre derinliğe kadarki ortalama standart penetrasyon darbe sayıs 1

$\mathrm{N}_{1,60 f}$ İnce dane içeriğine göre düzeltilmiş SPT vuruş sayısı 
$P_{\mathrm{tv}} \quad$ Temel tabanına etkiyen tasarım düşey basınç kuvveti, kazığa etkiyen düşey tasarım kuvveti

$\mathrm{P}_{1}$ ve $\mathrm{P}_{2} \quad$ Model parametreleri

p Yatay zemin direnci

Q Hareketli yük

$Q_{\mathrm{ks}} \quad$ Kazık karakteristik çevre sürtünmesi direnci

$Q_{\text {ku }} \quad$ Kazık karakteristik uç direnci

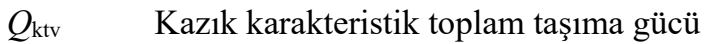

$Q_{\text {s }} \quad$ Kazık çevre sürtünmesi direnci

$Q_{\mathrm{tv}} \quad$ Kazığın düşey tasarım dayanımı

$Q_{\mathrm{u}} \quad$ Kazık uç direnci

$q_{\mathrm{k}} \quad$ Temel taşıma gücü karakteristik dayanımı

$q_{\mathrm{o}} \quad$ Temel seviyesinde etkiyen düşey yük, kesme ve moment etkilerinin oluşturduğu temel taban basinc1

$q_{\mathrm{t}} \quad$ Temel taşıma gücü tasarım dayanımı

$r_{u} \quad$ Boşluk suyu basıncı oranı

R Davranış katsayısı

$\mathrm{R}_{\mathrm{k}} \quad$ Karakteristik dayanım

$\mathrm{R}_{\text {rup }} \quad$ Faya olan uzaklik

$\mathrm{R}_{\mathrm{t}} \quad$ Tasarım dayanımı

$R_{\mathrm{pt}} \quad$ Tasarım pasif direnci

$R_{\text {th }} \quad$ Tasarım sürtünme direnci

S Model parametresi

SPT Standart penetrasyon deneyi

$\mathrm{S}_{\mathrm{DS}} \quad$ Kisa periyot tasarım spektral ivme katsayısı

$\mathrm{S}_{\mathrm{D} 1} \quad 1.0$ saniye periyot için tasarım spektral ivme katsayısı

$\mathrm{S}_{\mathrm{S}} \quad$ Kisa periyot harita spektral ivme katsayısı

$\mathrm{S}_{1} \quad 1.0$ saniye periyot için harita spektral ivme katsayısı

T Periyot

V Taban kesme kuvveti

$\mathrm{V}_{\mathrm{s}} \quad$ Kayma dalgası hızı 


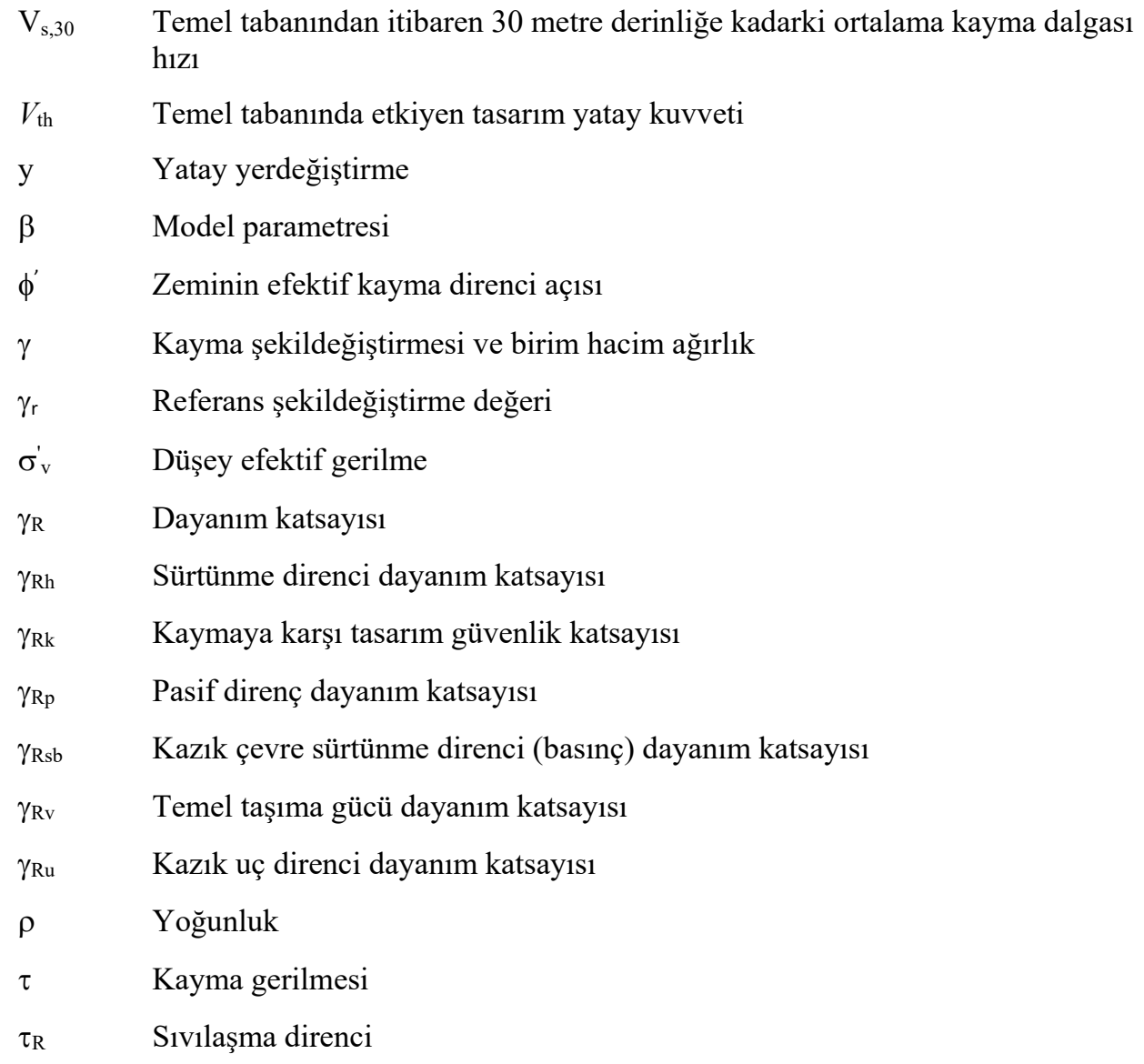

\section{Teșekkür}

Bu çalışma 119M624 kod nolu TÜBİTAK 1001 Bilimsel Araştırma Projesi kapsamında desteklenmiştir.

\section{Kaynaklar}

[1] TBDY, Türkiye Bina Deprem Yönetmeliği, AFAD, Türkiye, 2018.

[2] Hatanaka, M., \& Uchida, A., Emprical Correlation between Penetration Resistance and Internal Friction Angle of Sandy Soils. Soils and Foundations, Vol. 36, No.4, pp. 1-10, 1996.

[3] Kulhawy, F.H., \& Mayne, P.W., Manual on Estimating Soil Properties for Foundation Design. Electric Power Research Institute, Palo Alto, California, 1990. 
[4] Wair, B.R., DeJong, J.T. \& Shantz, T., Guidelines For Estimation Of Shear Wave Velocity Profiles. Pacific Earthquake Engineering Research (PEER) Center. PEER Report 2012/08, 2012.

[5] Youd, T. L., \& Idriss, I. M., Liquefaction resistance of soils: summary report from the 1996 NCEER and 1998 NCEER/NSF workshops on evaluation of liquefaction resistance of soils. Journal of geotechnical and geoenvironmental engineering, 127(4), 297-313, 2001.

[6] ASCE/SEI 7-10. Minimum design loads for buildings and other structures. 2010.

[7] NEHRP, Research Paper 12, Evaluation of geologic hazards and determination of seismic lateral earth pressures. Recommended Seismic Provisions, 2009.

[8] Akkar, S., Azak Eroğlu, T., Çan, T., Çeken, U., Demircioğlu M.B., Duman, T., Ergintav, S., Kadirioğlu, F.T., Kalafat, D., Kale, Ö., Kartal R.F., Kılıç, T., Özalp, S., Şeşetyan, K., Tekin, S., Yakıt, A., Yılmaz, M.T., Zülfikar, Ö., Türkiye Sismik Tehlike Haritasının Güncellenmesi. AFAD, Proje No: UDAP-Ç-13-06, 2014.

[9] Pacific Earthquake Engineering Research (PEER) Center, PEER Strong Motion Database, http://peer.berkeley.edu/smcat/, 2006.

[10] Ordonez, G.A., RSPMATCH. A computer program for GeoMotions. http://www.geomotions.com, 2005.

[11] Hashash, Y.M.A., Musgrove, M.I., Harmon, J.A., Ilhan, O., Groholski, D.R., Phillips, C.A., and Park, D., DEEPSOIL 7.0, User Manual. 2017.

[12] Kondner, R. L. and Zelasko, J. S., A hyperbolic stress-strain formulation of sands. Proceedings of the 2nd Pan American Conference on Soil Mechanics and Foundation Engineering, Sao Paulo, Brasil, 289-324, 1963.

[13] Matasovic, N, and Vucetic, M., Cyclic Characterization of Liquefiable Sands. ASCE Journal of Geotechnical and Geoenvironmental Engineering, Vol. 119, No. 11, pp 1805-1822, 1993.

[14] Darendeli, M.B., Development of a new family of normalized modulus reduction and material damping curves. Ph.D. Dissertation, The University of Texas at Austin, 2001.

[15] Chiaradonna, A., Bilotta, E., d'Onofrio, A., . Flora, A. \& Silvestri, F., A Simplified Procedure for Evaluating Post-Seismic Settlements in Liquefiable Soils. Geotechnical Earthquake Engineering and Soil Dynamics V, Austin, Texas, 2018

[16] Tokimatsu, K., \& Seed, H. B., Simplified procedures of the evaluation of settlements in clean sands. Rep. No. UCB/GT-84/16, University of California, USA, 1984.

[17] Ishihara, K., \& Yoshimine, M., Evaluation of settlements in sand deposits following liquefaction during earthquakes. Soils and foundations, 32(1), 173-188, 1992.

[18] Shamoto, Y., Zhang, J. M., \& Tokimatsu, K., New charts for predicting large residual post-liquefaction ground deformation. Soil dynamics and earthquake engineering, 17(7-8), 427-438, 1998. 
[19] Wu, J., Seed, R. B., and Pestana, J. M., Liquefaction triggering and post liquefaction deformations of Monterey 0/30 sand under unidirectional cyclic simple shear loading. Geotechnical Engineering Research Rep. No. UCB/GE-2003/01, University of California, USA, 2003.

[20] Cetin, K. O., Bilge, H. T., Wu, J., Kammerer, A. M., \& Seed, R. B., Probabilistic model for the assessment of cyclically induced reconsolidation (volumetric) settlements. Journal of Geotechnical and Geoenvironmental Engineering, 135(3), 387-398, 2009.

[21] Eurocode 7: Part 1, General Rules (together with United Kingdom National Application Document). London: British Standards Institution, 1995.

[22] CSI. SAP2000, V18.Integrated Software for Structural Analysis and Design. Berkeley, CA, USA: Computer andStructures Inc.(CSI), 2018.

[23] Reese, L. C., Cox, W. R., and Koop, F. D., Analysis of laterally loaded piles in sand. Proc. 6th Offshore Technology Conference, Paper 2080, Houston, Texas, pp. 473-483, 1974.

[24] American Petroleum Institute (API), Recommended practice for planning, designing and constructing fixed offshore platforms-working stress design. API Recommended Practice 2A(RP-2A WSD), 20th edn, 193 pp, 1993.

[25] Brandenberg, S.J., Boulanger, R.W., Kutter, B.L., Chang, D., Behavior of pile foundations in laterally spreading ground during centrifuge tests. J. Geotech. Geoenviron. Eng. 131(11):1378-1391, 2005. 
